\title{
Guidelines for Design and Sampling for Cyanobacterial Toxin and Taste-and-Odor Studies in Lakes and Reservoirs
}

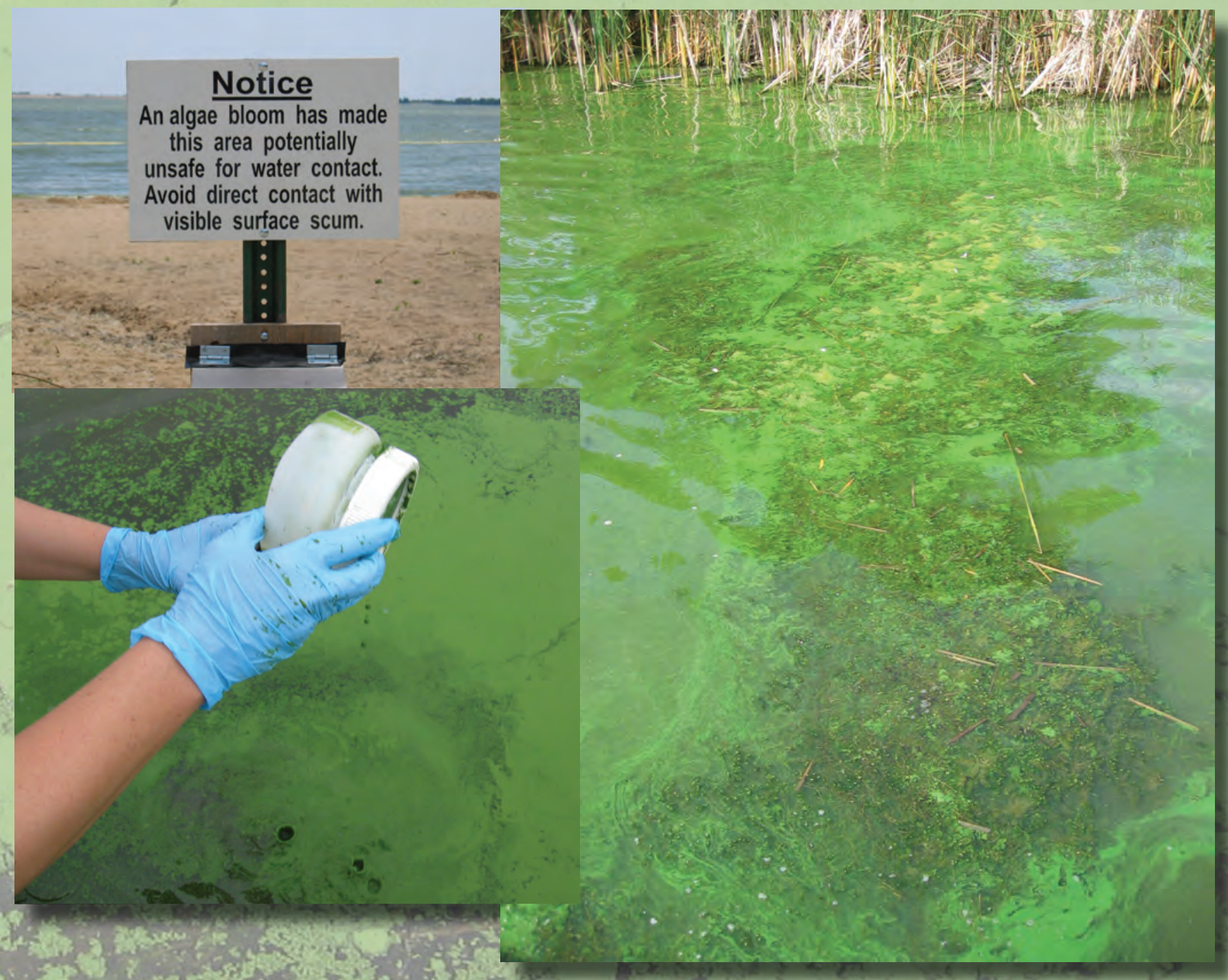

Scientific Investigations Report 2008-5038

U.S. Department of the Interior

U.S. Geological Survey 


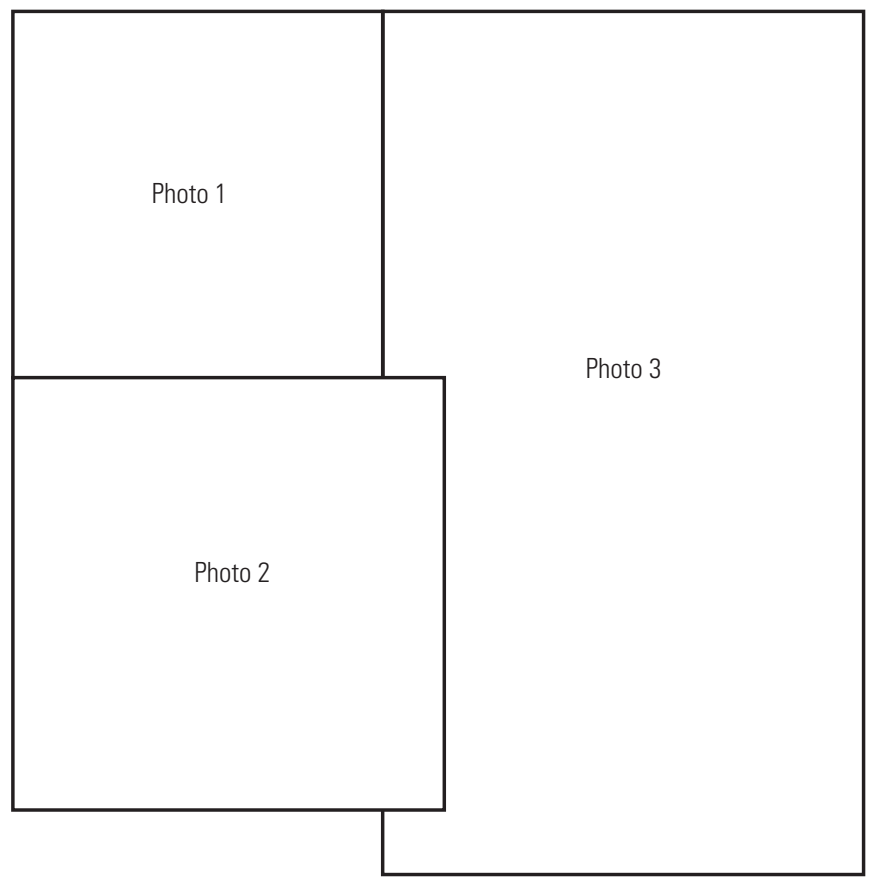

Front cover. Photograph 1: Beach sign warning of the presence of a cyanobacterial bloom, June 29, 2006 (photograph taken by Jennifer L. Graham, U.S. Geological Survey). Photograph 2: Sampling a near-shore accumulation of Microcystis, August 8, 2006 (photograph taken by Jennifer L. Graham, U.S. Geological Survey). Photograph 3: Mixed bloom of Anabaena, Aphanizomenon, and Microcystis, August 10, 2006 (photograph taken by Jennifer L. Graham, U.S. Geological Survey). Background photograph: Near-shore accumulation of Microcystis, August 8, 2006 (photograph taken by Jennifer L. Graham, U.S. Geological Survey). 


\section{Guidelines for Design and Sampling for Cyanobacterial Toxin and Taste-and-Odor Studies in Lakes and Reservoirs}

By Jennifer L. Graham, Keith A. Loftin, Andrew C. Ziegler, and Michael T. Meyer

Scientific Investigations Report 2008-5038 


\section{U.S. Department of the Interior DIRK KEMPTHORNE, Secretary}

\section{U.S. Geological Survey \\ Mark D. Myers, Director}

\section{U.S. Geological Survey, Reston, Virginia: 2008}

For product and ordering information:

World Wide Web: http://www.usgs.gov/pubprod

Telephone: 1-888-ASK-USGS

For more information on the USGS — the Federal source for science about the Earth, its natural and living resources, natural hazards, and the environment:

World Wide Web: http://www.usgs.gov

Telephone: 1-888-ASK-USGS

Any use of trade, product, or firm names is for descriptive purposes only and does not imply endorsement by the U.S. Government.

Although this report is in the public domain, permission must be secured from the individual copyright owners to reproduce any copyrighted materials contained within this report.

Suggested citation:

Graham, J.L., Loftin, K.A., Ziegler, A.C., and Meyer, M.T., 2008, Guidelines for design and sampling for cyanobacterial toxin and taste-and-odor studies in lakes and reservoirs: U.S. Geological Survey Scientific Investigations Report 2008-5038, 39 p. 


\section{Contents}

Abstract

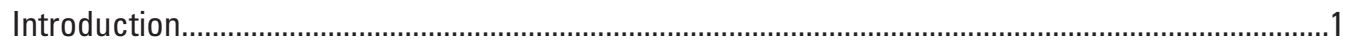

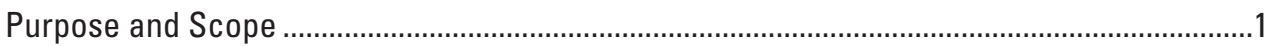

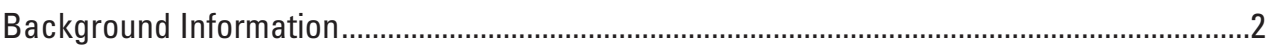

Light and Stratification in Lakes and Reservoirs .......................................................

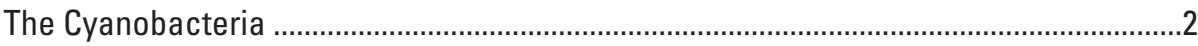

Cyanobacterial Toxins and Taste-and-Odor Compounds....................................................

Taste-and-Odor Production by Actinomycetes Bacteria .................................................

Detection of Cyanobacterial Toxins and Taste-and-Odor Compounds.............................8

Spatial and Temporal Variability of Cyanobacteria and Associated Toxins and Taste-and-Odor

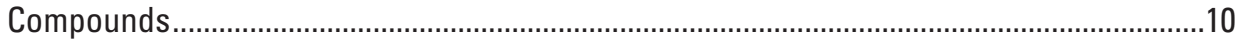

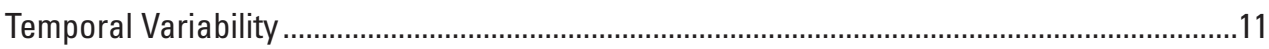

Spatial Variability in Lakes and Reservoirs ......................................................................

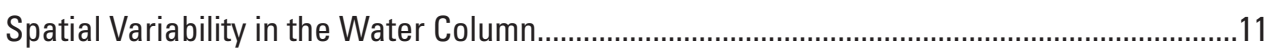

Common Study Types, Objectives, Designs, and Approaches for Studies of Cyanobacteria and

Associated Toxins and Taste-and-Odor Compounds .........................................................13

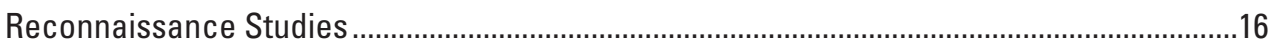

Monitoring Studies for Public Health and Drinking Water Treatment ...................................16

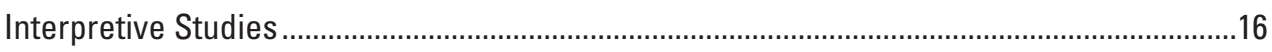

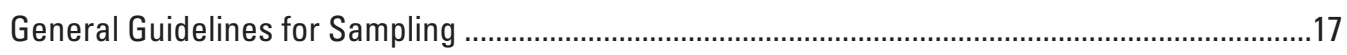

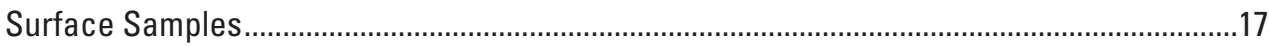

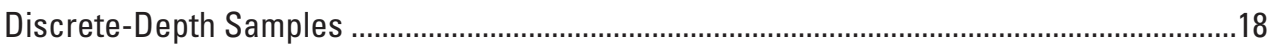

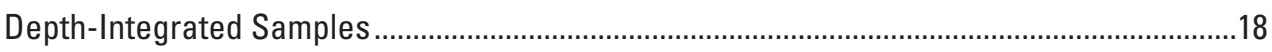

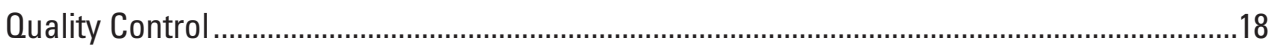

Sample Handling, Preparation, Processing, and Shipping for Analyses ..............................18

Sample Handling .......................................................................................................18

Processing Toxin and Taste-and-Odor Samples ........................................................18

Processing Cyanobacterial (Phytoplankton) Samples ..................................................21

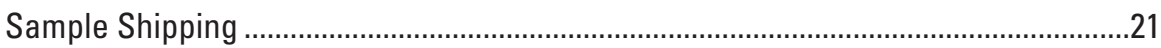

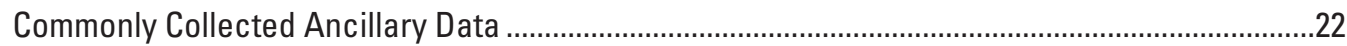

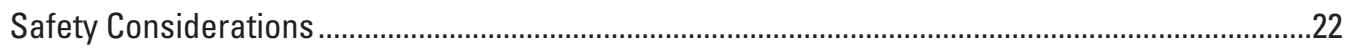

U.S. Geological Survey National Water Information System Parameter Codes................................22

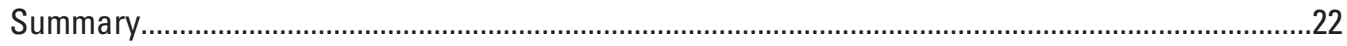

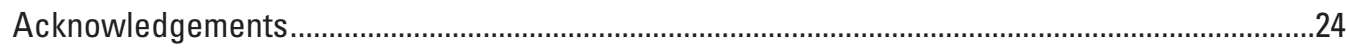

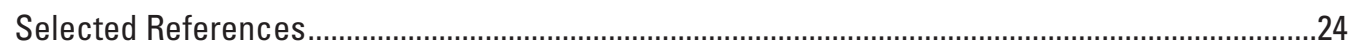

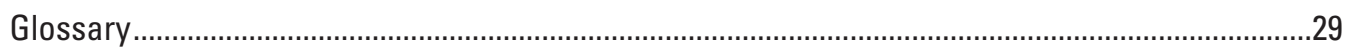

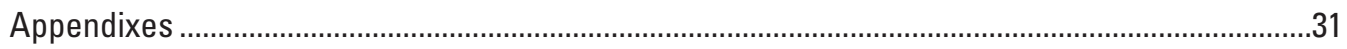

1. Example Design and Approach for a Regional Reconnaissance Study..........................32

2. Example Design and Approach for a Recreational Monitoring Study............................35

3. Example Design and Approach for an Interpretive Study to Develop a Real-Time Model to Estimate Geosmin and 2-methylisoborneol (MIB) Concentrations ....................37 


\section{Figures}

1. Schematic showing stratification and light, temperature, and oxygen gradients that may develop in lakes and reservoirs..

2. Photographs showing examples of cyanobacteria

3. Toxicity (lethal dose based on weight for 50 percent of the test population) of several cyanobacterial toxins

4. Schematic showing the theoretical temporal distribution of total, particulate, and dissolved cyanobacterial toxin concentrations with respect to cyanobacterial population density.

5. Photograph showing an example of spatial variability of cyanobacteria in a reservoir

6. Schematic showing potential water column distributions of cyanobacteria.

7. Photographs showing the appearance of potential water column distributions of cyanobacteria

8. Schematic showing temperature and oxygen gradients that will develop in the water column when a metalimnetic cyanobacterial bloom is present.

9. Schematic showing the partitioning of cyanobacterial toxins and taste-and-odor compounds among the total, particulate, and dissolved phases in different types of samples.

\section{Tables}

1. Common genera of planktonic cyanobacteria that contain toxin and taste-and-odor producing strains

2. Common cyanobacterial toxins, toxicity (based on intraperitoneal mouse assays), and common effects of exposure

3. Relative advantages and disadvantages of common analytical techniques utilized for analysis of cyanobacterial toxins and taste-and-odor compounds.

4. General study objectives and guidelines describing when, where, and how samples typically are collected for reconnaissance studies

5. General study objectives and guidelines describing when, where, and how samples typically are collected for monitoring studies

6. General study objectives and guidelines describing when, where, and how samples typically are collected for interpretive studies assessing the physical, chemical, and biological factors affecting the occurrence and concentration of cyanobacteria and associated toxins and taste-and-odor compounds

7. Samplers commonly used to collect surface, discrete depth, and depth integrated samples in lakes and reservoirs

8. Commonly collected ancillary data for studies of cyanobacterial toxins and taste-andodor compounds and references for additional information..... 


\section{SI to Inch/Pound}

\begin{tabular}{lll}
\hline \multicolumn{1}{c}{ Multiply } & \multicolumn{1}{c}{ By } & \multicolumn{1}{c}{ To obtain } \\
\hline centimeter $(\mathrm{cm})$ & 0.3937 & inch (in.) \\
cubic micrometer $\left(\mu \mathrm{m}^{3}\right)$ & $6.102 \times 10^{-14}$ & cubic inch (in $\left.{ }^{3}\right)$ \\
cubic micrometers per milliliter $\left(\mu \mathrm{m}^{3} / \mathrm{mL}\right)$ & $1.805 \times 10^{-12}$ & cubic inch per ounce \\
liter $(\mathrm{L})$ & 33.82 & ounce, fluid (fl. oz) \\
liter $(\mathrm{L})$ & 2.113 & pint $(\mathrm{pt})$ \\
liter $(\mathrm{L})$ & 1.057 & quart $(\mathrm{qt})$ \\
liter $(\mathrm{L})$ & 0.2642 & gallon $(\mathrm{gal})$ \\
meter $(\mathrm{m})$ & 3.281 & foot $(\mathrm{ft})$ \\
meter $(\mathrm{m})$ & 1.094 & yard $(\mathrm{yd})$ \\
microgram per gram $(\mu \mathrm{g} / \mathrm{g})$ & $1.600 \times 10^{-6}$ & ounce per pound $(\mathrm{oz} / \mathrm{lb})$ \\
microgram per kilogram $(\mu \mathrm{g} / \mathrm{kg})$ & $1.600 \times 10^{-8}$ & ounce per pound $(\mathrm{oz} / \mathrm{lb})$ \\
microgram per liter $(\mu \mathrm{g} / \mathrm{L})$ & 1.0 & part per billion $(\mathrm{ppb})$ \\
micrometer $(\mu \mathrm{m})$ & $3.937 \times 10^{-6}$ & inch (in.) \\
milliliter $(\mathrm{mL})$ & 0.0338 & ounce, fluid $(\mathrm{oz})$ \\
nanogram per liter $(\mathrm{ng} / \mathrm{L})$ & 1.0 & part per trillion $(\mathrm{ppt})$ \\
\hline
\end{tabular}

Temperature in degrees Fahrenheit $\left({ }^{\circ} \mathrm{F}\right)$ may be converted to degrees Celsius $\left({ }^{\circ} \mathrm{C}\right)$ as follows:

${ }^{\circ} \mathrm{C}=\left({ }^{\circ} \mathrm{F}-32\right) / 1.8$

Temperature in degrees Celsius $\left({ }^{\circ} \mathrm{C}\right)$ may be converted to degrees Fahrenheit $\left({ }^{\circ} \mathrm{F}\right)$ as follows:

${ }^{\circ} \mathrm{F}=\left(1.8 x^{\circ} \mathrm{C}\right)+32$. 



\title{
Guidelines for Design and Sampling for Cyanobacterial Toxin and Taste-and-Odor Studies in Lakes and Reservoirs
}

\author{
By Jennifer L. Graham, Keith A. Loftin, Andrew C. Ziegler, and Michael T. Meyer
}

\section{Abstract}

Cyanobacteria and associated toxins and taste-and-odor compounds are of increasing environmental concern. However, consistent guidelines for the development of studies assessing cyanobacterial toxins and taste-and-odor compounds presently are not available. This report provides guidance for the development of scientific studies of cyanobacteria and associated by-products in lakes and reservoirs. Topics include: background information on cyanobacteria, toxins, and tasteand-odor compounds; spatial and temporal considerations that are unique to the cyanobacteria in lakes and reservoirs; common study types, objectives, and approaches for studies of cyanobacteria and associated toxins and taste-and-odor compounds; general guidelines for collecting samples; and information on sample handling, preparation, processing, and shipping.

\section{Introduction}

Cyanobacteria (also referred to as blue-green algae) cause a multitude of water-quality concerns, including the potential to produce toxins and taste-and-odor compounds. Toxins and taste-and-odor compounds may cause significant economic and public health concerns, and are of particular interest in lakes, reservoirs, and rivers that are used for drinking-water supply, recreation, or aquaculture. Cyanobacterial toxins (cyanotoxins) have been implicated in human and animal illness and death in more than 50 countries worldwide, including at least 27 states in the United States (Yoo and others, 1995; Chorus and Bartram, 1999; Huisman and others, 2005). Human toxicoses associated with cyanobacterial toxins most commonly have occurred after exposure through drinking water or recreational activities (Yoo and others, 1995; Chorus and Bartram, 1999; Falconer, 2005; Huisman and others, 2005; Graham, 2006). Taste-and-odor compounds cause malodorous or unpalatable drinking water and fish flesh, resulting in increased treatment costs and loss of recreational or aquacultural revenue. Federal and state agencies, resource managers, drinking-water treatment-facility operators, lake associations, and local officials increasingly are faced with decisions about managing cyanobacterial blooms that affect local economies and public awareness, exposure, and health; therefore, representative scientific data are needed to guide management and public health decisions about cyanobacterial toxins and taste-and-odor compounds.

The study of cyanobacterial toxins and taste-and-odor compounds is an active area of developing research. Many different approaches have been used in the design, sample collection, and analysis of studies addressing these cyanobacterial by-products. Consistent guidelines for the development of such studies presently (2008) are not available, often making cross-comparisons difficult (Graham and Jones, 2007).

As part of its mission, the U.S. Geological Survey (USGS) collects the data needed to assess the quality of our Nation's water resources. A key aspect of this mission is consistent use of field methods for the purpose of producing nationally comparable data. There is a need for citable documentation for USGS water-quality data-collection protocols for scientific studies of cyanobacteria and associated by-products in lakes and reservoirs.

\section{Purpose and Scope}

The purpose of this report is to provide guidelines for design and sampling for cyanobacterial toxin and taste-andodor compounds in lakes and reservoirs. This report: provides general background information on cyanobacteria and associated toxins and taste-and-odor compounds; discusses special considerations for study design and sampling approaches that are unique to planktonic cyanobacteria and associated toxin and taste-and-odor compounds; provides guidance on appropriate sampling approaches for the system being studied; and provides guidance on sample collection, handling, preparation, processing, and shipping for laboratory analysis of toxins and taste-and-odor compounds, and algal identification, enumeration, and biovolume.

The fundamentals of study design are beyond the scope of this report, but there are special characteristics of planktonic cyanobacteria that need to be considered when developing cyanobacterial toxin and taste-and-odor studies. The information provided in this report is intended to be used in conjunction with other reports that specifically address the design of 
surface-water-quality studies (Friedman and Erdmann, 1982; Shampine and others, 1992; Averett and Schroder, 1994).

In addition to planktonic cyanobacteria, benthic

cyanobacteria in lakes, reservoirs, streams, and rivers also may produce toxins and taste-and-odor compounds (Chorus and Bartram, 1999; Falconer, 2005; Huisman and others, 2005; Taylor and others, 2005). Although consistent guidelines presently (2008) are not available for collecting samples and designing studies of benthic cyanobacteria, sampling this component in aquatic ecosystems, especially streams, is beyond the scope of this report. Other algal groups besides cyanobacteria also may cause taste-and-odor problems in drinkingwater supplies; however, the most frequent and severe events are associated with cyanobacteria (Wnorowski, 1992; Rashash and others, 1996; Taylor and others, 2005). One other freshwater/brackishwater alga (the haptophyte Prymnesium parvum) is known to produce icthyotoxins, but these toxins have been associated with fish kills only, and not human illness (Sager and others, 2007). All approaches presented in this report are discussed with an emphasis on the cyanobacteria; but these procedures also may be applicable for studies of other planktonic algal groups, depending on study objectives.

\section{Background Information}

\section{Light and Stratification in Lakes and Reservoirs}

Lakes and reservoirs are characterized by vertical gradients caused by light and thermal stratification. An understanding of these gradients is required when designing studies and sampling strategies for lakes and reservoirs. Key terms and concepts are described herein. For more detail on light and thermal stratification in lakes and reservoirs see: Horne and Goldman (1994), Lampert and Sommer (1997), Wetzel and Likens (2000), and Wetzel (2001).

Light intensity decreases exponentially with depth, and a light gradient is present in all lakes (fig. 1) (Horne and Goldman, 1994; Lampert and Sommer, 1997; Wetzel and Likens, 2000; Wetzel, 2001). Common terms used to describe light gradients in lakes include:

Photic (Euphotic) Zone-Region where there is enough light to support photosynthesis; extends from the surface to the depth where light is approximately 1 percent of that at the surface.

Aphotic Zone-Region where there is not enough light to support photosynthesis; extends from below the photic zone to the lake bottom.

Thermal stratification creates isolated layers that result in thermal and chemical (such as nutrient) gradients; stratification is the result of differences in density associated with temperature (fig. 1). Stratification in deep lakes tends to be stable, whereas daily or continual mixing may occur in shallow lakes. Thermal stratification is a summer phenomenon in temperate lakes, but may occur year round in sub-tropical and tropical lakes. Spatial variability of stratification within lakes and reservoirs is common because of changes in depth and other morphological features (Horne and Goldman, 1994; Lampert and Sommer, 1997; Wetzel and Likens, 2000; Wetzel, 2001). Common terms used to describe stratification include:

Epilimnion-The warm, buoyant upper layer of a stratified lake.

Metalimnion-The middle layer of a stratified lake; the metalimnion is characterized by substantial decreases in temperature with depth.

Thermocline-The region where temperature change is greater than or equal to $1^{\circ} \mathrm{C}$ per meter; the terms thermocline and metalimnion often are used synonymously.

Hypolimnion - The cold, dense bottom layer of a stratified lake; the hypolimnion often becomes anoxic (little or no dissolved oxygen) in productive systems.

Turnover - Complete isothermal mixing of a previously stratified lake.

Mixed Depth-The depth of turbulent mixing; may include all or only a part of the water column depending on stratification, solar irradiance, and wind.

During calm periods temporary mixed layers (lasting hours-weeks) may form in shallow lakes, deeper lakes that do not typically stratify, or the epilimnion of stratified lakes, creating greater complexity in vertical structure. Mixing in shallow and stratified lakes will vary daily and seasonally depending on solar irradiance and wind. Thermal stratification is most common, but gradients in water chemistry (often caused by submerged springs), such as salinity, also may cause stratification (Horne and Goldman, 1994; Lampert and Sommer, 1997; Wetzel and Likens, 2000; Wetzel, 2001).

\section{The Cyanobacteria}

Cyanobacteria (fig. 2) are true bacteria with a prokaryotic cell structure; however, cyanobacteria also have chlorophyll- $a$, a photopigment characteristic of eukaryotic algae and higher plants. Structurally the cyanobacteria are bacteria-like, but functionally the cyanobacteria are algae-like. Because of this photosynthetic functionality, cyanobacteria typically are sampled and analyzed as part of phytoplankton (algal) assemblages rather than bacterial assemblages in aquatic ecosystems (Wetzel, 2001).

Cyanobacteria are a natural part of phytoplankton assemblages in lakes and reservoirs and commonly are present in at least low abundances (Reynolds, 1984; Jones and Korth, 1995). Cyanobacterial abundance and community composition vary seasonally as a result of changes in water temperature, solar irradiance, meteorological conditions, hydrology, and nutrient supply. In temperate climates, cyanobacteria typically dominate the phytoplankton during mid-summer to early fall, but may become dominant any time throughout the year, even under ice during winter. In subtropical and tropical climates cyanobacteria may dominate at any time, and dominance may persist year-round (Chorus and Bartram, 1999; Wetzel, 2001; Falconer, 2005; Huisman and others, 2005). 


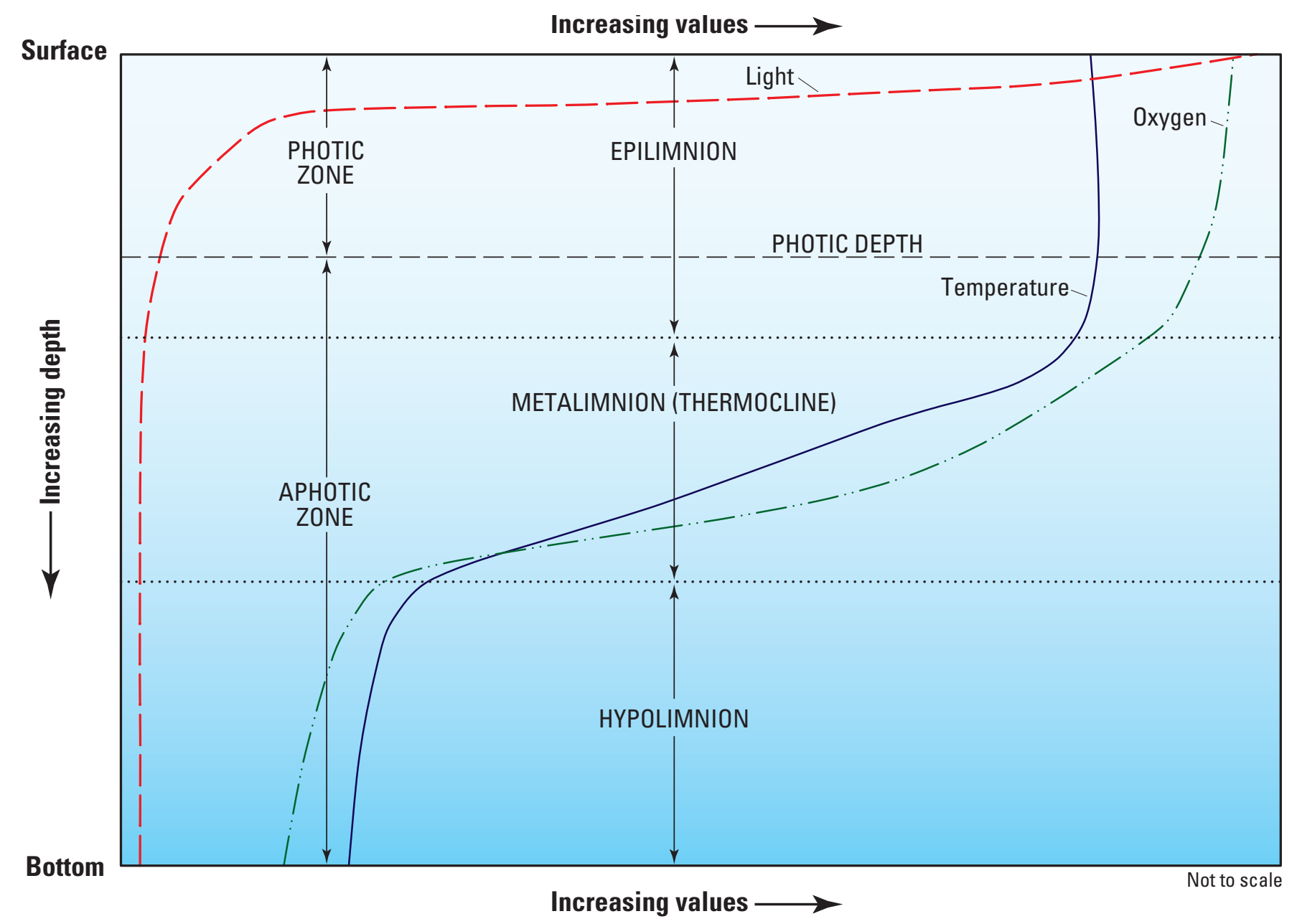

Figure 1. Stratification and light, temperature, and oxygen gradients that may develop in lakes and reservoirs.

Eutrophication results in conditions that are favorable for cyanobacterial growth (elevated nutrients, reduced light penetration) and cyanobacterial blooms frequently occur in eutrophic (nutrient rich, high productivity) lakes and reservoirs. Cyanobacterial blooms also may occur in oligotrophic (nutrient poor, low productivity) systems, although not as frequently as in eutrophic systems. Blooms in oligotrophic systems often are associated with benthic mats of cyanobacteria or favorable nutrient and light conditions at depth in a stably stratified water column (Reynolds, 1984; Chorus and Bartram, 1999; Wetzel, 2001; Falconer, 2005; Huisman and others, 2005).

Many, but not all, cyanobacteria have gas vacuoles that allow them to maintain a favorable position in the water column by regulating buoyancy. Light (photic depth), nutrients, carbon availability, stratification, and mixed depth (depth of turbulent mixing in the water column) all affect cyanobacterial position in the water column. Optimal water-column position is species specific. There are three distinct patterns in distribution that may develop (Reynolds and Walsby, 1975; Reynolds, 1987; Humphries and Lyne, 1998):
1. Cyanobacteria may maintain a position in the photic zone, regardless of mixed depth. Populations typically are uniformly distributed throughout the photic zone. This distribution may develop in well-mixed lakes or the epilimnion of stably stratified lakes. Many cyanobacterial genera, including Anabaena, Aphanizomenon, Cylindrospermopsis, and Microcystis display this type of buoyancy regulation.

2. Cyanobacteria may migrate to different locations in the photic zone throughout the day. Populations generally move towards the surface at night or early morning and downwards later in the day. Diel movement of cyanobacterial populations typically is linked with the development of diel mixed layers in shallow lakes or the epilimnion of stably stratified lakes. Regardless of movement or location, cyanobacteria typically maintain a position in the photic zone. In shallow lakes, where light penetrates to the bottom, cyanobacteria may spend part of the day on the sediment surface. Diel movement most commonly is associated with species of Microcystis. 


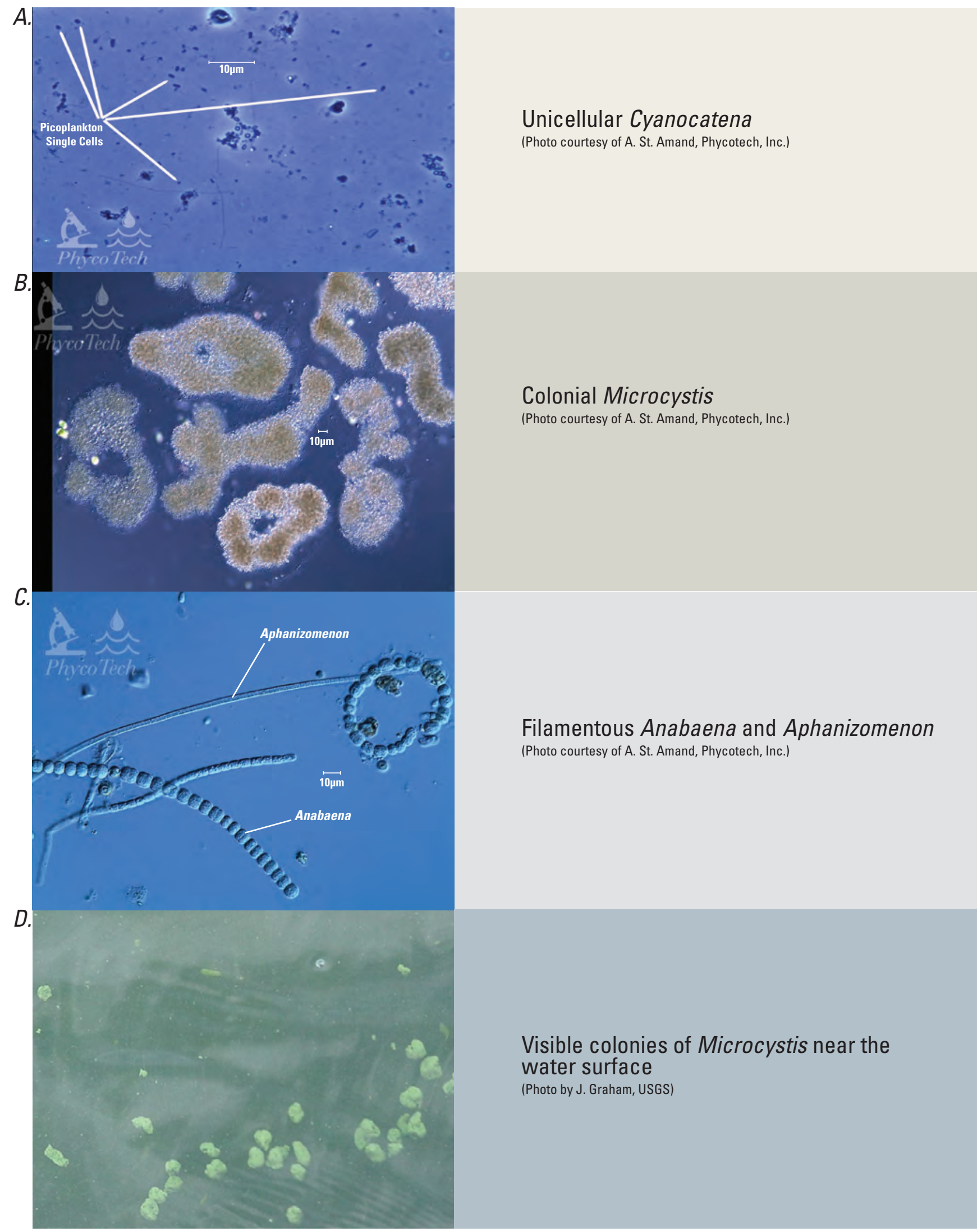

Figure 2. Examples of cyanobacteria: Cyanobacteria may be unicellular $(A)$, colonial $(B)$, or filamentous $(C)$ and range in size from 0.2 micrometers to greater than 1,600 micrometers. Larger filaments and colonies are often visible to the naked eye (D). 
3. Cyanobacteria may maintain a position at a particular depth, typically at the interface between the epilimnion and metalimnion. This phenomenon is referred to as a metalimnetic bloom, and most commonly is associated with species of Planktothrix (Oscillatoria). Metalimnetic cyanobacterial blooms occur most frequently in mesotrophic (moderate nutrients and productivity) lakes. For metalimnetic blooms to develop, the water column must be stably stratified and photic depth must penetrate into the metalimnion; metalimnetic cyanobacterial blooms can exist at light levels at or below one percent of incident light.

The term bloom, not specific to cyanobacteria, is inexact and subjective (Smayda, 1997). The simplest definitions are: a large population or extremely high cell densities of phytoplankton (extremely high densities are typically defined as greater than 20,000 to 100,000 cells per milliliter); where proliferation of phytoplankton is dominated by a single or a few species; or visible accumulation of phytoplankton at the water surface (Cottingham and others, 1995; Chorus and Bartram, 1999; Dodds, 2002; Huisman and others, 2005; Falconer and Humpage, 2006; Jacoby and Kann, 2007).

When referring to cyanobacteria, the term bloom commonly is associated with the accumulation of cyanobacteria at the water surface; however, cyanobacterial blooms are more typically mixed throughout the photic zone, epilimnion, or water column. Surface accumulations, or scums, may develop when cyanobacteria float to the surface during unusually calm conditions that cause a sudden change in turbulent mixing (sudden calm will not affect metalimnetic populations) or when cyanobacteria begin to senesce (age) and are no longer able to effectively regulate buoyancy. Surface accumulations may develop and dissipate within a matter of hours as conditions change. Because the entire cyanobacterial population may accumulate within 1 to 2 centimeters of the water surface, cell densities may be extremely large (more than a million cells per milliliter), even if water-column densities were relatively small (less than 20,000 cells per milliliter). Surface accumulations of cyanobacteria may concentrate even further when wind blows to leeward areas (for example, near-shore areas, bays, and inlets), often resulting in the development of dense accumulations that may extend from the surface to depths of more than 1 meter (Reynolds and Walsby, 1975; Reynolds, 1987; Soranno, 1997; Humphries and Lyne, 1998; Chorus and Bartram, 1999; Dodds, 2002; Falconer, 2005; Huisman and others, 2005; Jacoby and Kann, 2007).

\section{Cyanobacterial Toxins and Taste-and-0dor Compounds}

Cyanobacterial toxins and taste-and-odor compounds are naturally produced algal by-products; however, the function of these compounds currently (2008) is unknown. Hypothesized functions include primary roles in cellular processes, secondary metabolites, allelopathy, or defense mechanisms.
Production of toxins and taste-and-odor compounds is strain, rather than species, dependent. Any one cyanobacterial species may have multiple strains, and toxic and non-toxic strains may occur simultaneously in an individual lake (Vezie and others, 1998). Most cyanobacterial taxa do not produce toxins or taste-and-odor compounds, but many of the common planktonic genera contain one or more toxin and/or taste-andodor producing strains (table 1). Whereas some strains may produce toxin and taste-and-odor compounds simultaneously, these compounds do not necessarily co-occur and the presence and concentration of one may not be reliably used to predict the presence and concentration of another (Chorus and Bartram, 1999). Because toxin and taste-and-odor production is strain dependent, algal identification alone cannot be used to determine whether or not these by-products will be present, although genera that contain strains producing these compounds can be identified. Likewise, co-occurrence of potential producers and toxin and/or taste-and-odor compounds does not positively identify the actual producer. Strain isolation and culture are required to conclusively determine the producer(s) of measured toxin and/or taste-and-odor compounds (Chorus and Bartram, 1999; Watson, 2003; Falconer, 2005; Huisman and others, 2005; Taylor and others, 2005). Genetic techniques that isolate specific gene clusters also are promising in identifying toxin producers in complex environmental samples (Nonneman and Zimba, 2002; Hisbergues and others, 2003; Kurmayer and Kutzenberger, 2003; Vaitomaa and others, 2003).

Cyanobacterial toxins are chemically and bioactively diverse (Sivonen, 1996; Carmichael, 1997; Chorus and Bartram, 1999), all targeting fundamental cellular processes, and thereby affecting a wide range of organisms (Falconer, 1993; Christofferson, 1996). The cyanobacteria are the only member of freshwater phytoplankton communities known to produce toxins that also may affect terrestrial organisms. The three main classes of cyanobacterial toxins, defined by their effects on human health, are dermatoxins, neurotoxins, and hepatotoxins (Chorus, 1993; Chorus and Bartram, 1999; Falconer, 1999). Dermatoxins cause acute, often severe, dermatitis after contact with cyanobacteria, and also may cause inflammation of the gastro-intestinal tract (Volterra, 1993; Chorus, 1993; Sivonen, 1996; Chorus and Bartram, 1999; Stewart and others, 2006). Neurotoxins, which affect the central nervous system, and hepatotoxins, which affect the liver, are extremely toxic, and numerous wild and domestic animal kills have been linked to such blooms. Whereas neurotoxins rarely are associated with human illness and death, human toxicoses associated with hepatotoxins have occurred after consumption of drinking water, contact with cyanobacteria during recreational activities (including inhalation exposure), and haemodialysis using tainted water (Chorus, 1993; Volterra, 1993; Carmichael and others, 2001; Chorus and Bartram, 1999; Falconer, 2005; Huisman and others, 2005).

The most common cyanobacterial toxin groups are described in figure 3 and table 2. Many of the cyanobacterial toxins have multiple variants, with some variants being more 
Table 1. Common genera of planktonic cyanobacteria that contain toxin and taste-and-odor producing strains.

[All data included in this table are based on documented production in laboratory cultures; data based on circumstantial evidence, such as co-occurrence of genera and toxin or taste-and-odor compounds in environmental samples, were not included in this table. LYN, lyngbyatoxin-a; APL, aplysiatoxins; LPS, lipopolysaccharides; CYL, cylindrospermopsins; MC, microcystins; NOD, nodularins; ATX, anatoxins; BMAA, $\beta$-N-methylamino-L-alanine; NEO, neosaxitoxins; SAX, saxitoxins; GEOS, geosmin; MIB, 2-methylisoborneol]

\begin{tabular}{|c|c|c|c|c|c|c|c|c|c|c|c|c|}
\hline \multirow{2}{*}{ Cyanobacterial Genera } & \multicolumn{3}{|c|}{ Dermatoxins } & \multicolumn{3}{|c|}{ Hepatotoxins } & \multicolumn{4}{|c|}{ Neurotoxins } & \multicolumn{2}{|c|}{$\begin{array}{l}\text { Tastes and } \\
\text { odors }\end{array}$} \\
\hline & LYN & APL & LPS & CYL & MC & NOD & ATX & BMAA & NEO & SAX & GEOS & MIB \\
\hline Anabaena & & & $\mathrm{X}$ & $\mathrm{X}$ & $\mathrm{X}$ & & $\mathrm{X}$ & $\mathrm{X}$ & $\mathrm{X}$ & $\mathrm{X}$ & $\mathrm{X}$ & \\
\hline Anabaenopsis & & & $\mathrm{X}$ & & $\mathrm{X}$ & & & & & & & \\
\hline Aphanocapsa & & & $\mathrm{X}$ & & $\mathrm{X}$ & & & & & & & \\
\hline Cylindrospermopsis & & & $\mathrm{X}$ & $\mathrm{X}$ & & & & $\mathrm{X}$ & & $\mathrm{X}$ & & \\
\hline Microcystis & & & $X$ & & $X$ & & & $X$ & & & & \\
\hline Nodularia & & & $\mathrm{X}$ & & & $\mathrm{X}$ & & $\mathrm{X}$ & & & & \\
\hline \multicolumn{13}{|c|}{ Unicellular } \\
\hline Synechococcus & & & $\mathrm{X}$ & & $\mathrm{X}$ & & & $\mathrm{X}$ & & & $\mathrm{X}$ & $\mathrm{X}$ \\
\hline Synechocystis & & & $\mathrm{X}$ & & $X$ & & & $\mathrm{X}$ & & & & \\
\hline
\end{tabular}

Sources: Wu and others (1991), Wnorowski (1992), Blevins and others (1995), Carmichael (1997), Bláha and Maršálek (1999), Chorus and Bartram (1999),

Domingos and others (1999), Saadoun and others (2001), Oudra and others (2002), Watson (2003), Huisman and others (2005), and Taylor and others (2005).

A comprehensive list of known cyanobacterial toxin and taste-and-odor producers is not currently (2008) available in the literature. Combined, the references used to create this table may be used to create a fairly complete list of planktonic and benthic producers.

toxic than others. For example, the microcystins, currently believed to be the most common group of cyanobacterial toxins, have more than 80 known variants with $\mathrm{LD}_{50}$ 's (lethal dose required to kill 50 percent of the test population; determined by intraperitoneal mouse assays) ranging from 25 to greater than 1,000 micrograms per kilogram $(\mu \mathrm{g} / \mathrm{kg}$ ) (most variants fall within the 50-300 $\mu \mathrm{g} / \mathrm{kg}$ range). The adverse health effects caused by contact with, or ingestion or inhalation of, large concentrations of cyanobacterial toxins (acute exposure) are well documented (table 2). The effects of exposure to low levels of cyanobacterial toxins for an extended period of time (chronic exposure) are not well understood. Several of the dermatoxins and hepatotoxins also are known to be potent tumor promoters (Chorus and Bartram, 1999); however, the effects of chronic exposure to low doses of cyanobacterial toxins with time are largely unknown. The recently discovered neurotoxin $\beta$-N-methylamino-L-alanine (BMAA) is unique in that it does not have known acute effects on human health, but chronic exposure to BMAA may be linked to neurodegenerative diseases such as ALS (amyotrophic lateral sclerosis), Parkinson's, and Alzheimer's (Cox and others, 2005). Unlike toxins, cyanobacterial taste-and-odor compounds have no known effects on human health (Watson, 2003).
The greatest risk of exposure to elevated concentrations of cyanobacterial toxins probably is through accidental ingestion and inhalation during recreational activities. The World Health Organization (WHO) has defined low, moderate, high, and very high risk categories for adverse health effects that occur through recreational exposure to microcystins. Based on the WHO risk categories for recreational exposure, microcystin concentrations less than 10 micrograms per liter $(\mu \mathrm{g} / \mathrm{L})$ have a low risk, $10-20 \mu \mathrm{g} / \mathrm{L}$ a moderate risk, $20-2000 \mu \mathrm{g} / \mathrm{L}$ a high risk, and greater than $2000 \mu \mathrm{g} / \mathrm{L}$ a very high risk for adverse health effects (Chorus and Bartram, 1999). WHO recreational guidelines do not distinguish between children and adults, although children are considered to be at greater risk because of low body mass and their tendency to ingest water while playing (Chorus, 2001).

The WHO also has developed a provisional guideline of $1 \mu \mathrm{g} / \mathrm{L}$ for microcystin-LR in finished drinking water (Chorus and Bartram, 1999) and currently (2008) is developing a guideline for cylindrospermopsin. Falconer (2005) has proposed a guideline of $1 \mu \mathrm{g} / \mathrm{L}$ for cylindrospermopsin in finished drinking water. Several countries have set national standards or guidelines for microcystin in drinking water based on the WHO guideline, including Australia, Brazil, Canada, the Czech Republic, France, Poland, and Spain (Huisman and 


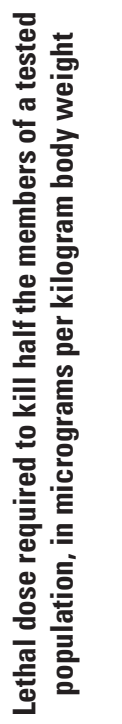

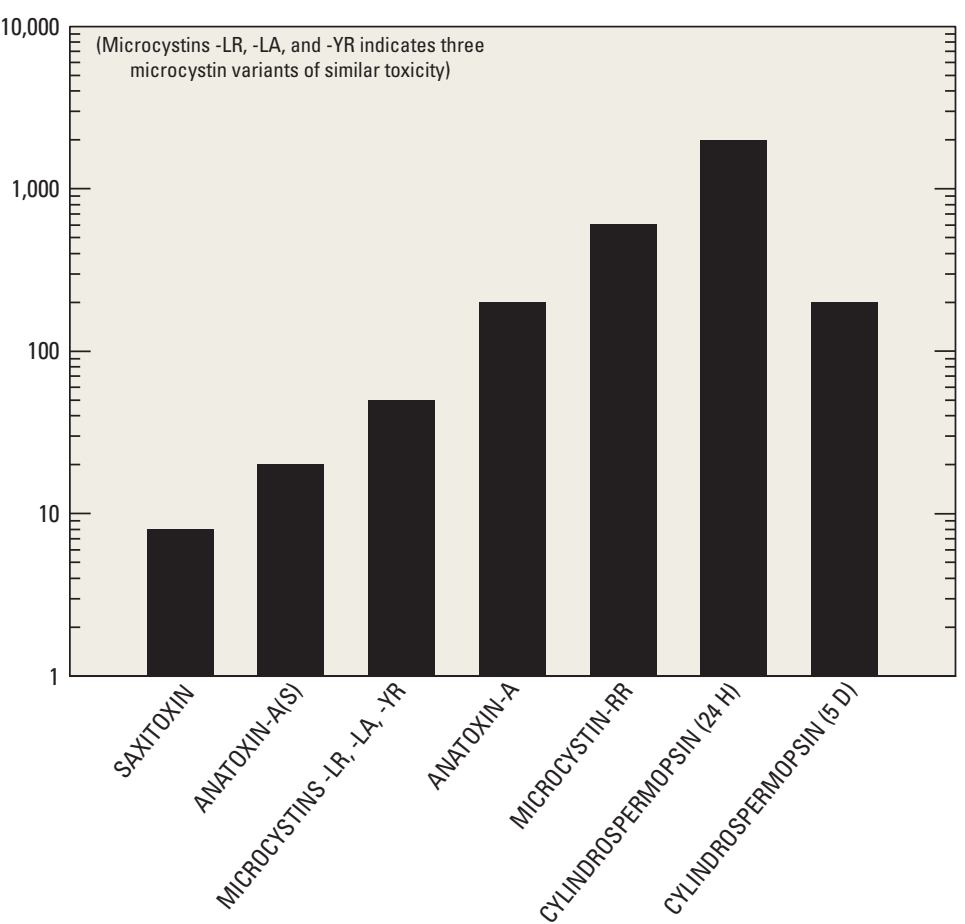

Algal Toxins
Figure 3. Toxicity (lethal dose based on weight for 50 percent of the test population) of several cyanobacterial toxins. Toxicity is based on intraperitoneal mouse assays (table 2). Figure based on data from Chorus and Bartram (1999). others, 2005), and in the United States the cyanobacterial toxins microcystin, cylindrospermopsin, and anatoxin currently are on the U.S. Environmental Protection Agency (2005) drinking-water contaminant candidate list.

There are many potential sources of taste-and-odor in finished drinking water, including biological activity in the source water, chemical contamination (natural and anthropogenic) of the source water, chemicals used in treatment processes, and biological activity or materials present in the distribution system. Biological activity associated with naturally occurring algae in source water is among the most common causes of tastes and odors in finished drinking water (Rashash and others, 1996; Taylor and others, 2005; Watson, 2003; Wnorowski, 1992). Many groups of algae produce tasteand-odor compounds, with approximately 200 different compounds identified to date (2008) (Rashash and others, 1996; Watson, 2003; American Water Works Association, 2004); however, most taste-and-odor problems in drinking water are associated with cyanobacterial production of geosmin and 2-methylisoborneol (MIB) (Wnorowski, 1992; Rashash and others, 1996; Taylor and others, 2005).

The taste-and-odor compounds geosmin and MIB cause earthy/musty tastes and odors and are detectable by humans at concentrations between 5-10 nanograms per liter; therefore, these compounds may be detectable in the environment before potential cyanobacterial producers are detected. In addition, the producer may be a relatively small component of the phytoplankton community. Taste-and-odor episodes caused by cyanobacteria have occurred even when cyanobacteria are not at detectable levels in the water column (Wnorowski, 1992;
Jones and Korth, 1995; Rashash and others, 1996; Watson, 2003; Taylor and others, 2005).

\section{Taste-and-0dor Production by Actinomycetes Bacteria}

Most taste-and-odor problems associated with geosmin and/or MIB are caused by cyanobacteria but bacteria in the actinomycetes group also may produce geosmin and MIB (Wnorowski, 1992; Rashash and others, 1996; Watson, 2003; Taylor and others, 2005). Actinomycetes bacteria are not photosynthetic and are not part of the phytoplankton community in lakes and reservoirs. The actinomycetes bacteria largely are terrestrial organisms associated with soils; tasteand-odor compounds typically are produced terrestrially and washed into lakes or reservoirs with or without the bacteria that produced them. Inflow events with high suspendedsediment loads may result in taste-and-odor episodes caused by geosmin/MIB produced by actinomycetes bacteria (Zaitlin and others, 2003; Zaitlin and Watson, 2006). When washed in, actinomycetes bacteria generally are associated with the sediment. However, taste-and-odor compounds produced by actinomycetes bacteria can be located in the water column and throughout the lake or reservoir, depending on whether the compounds are dissolved or associated with the bacteria, hydrology of inflows and mixing with surrounding water, and sediment settling rates. Because of settling, actinomycetes may accumulate in the hypolimnion or near the bottom of lakes or reservoirs. It currently (2008) is unknown if or for how long terrestrial actinomycetes bacteria remain metabolically active 
Table 2. Common cyanobacterial toxins, toxicity (based on intraperitoneal mouse assays), and common effects of exposure.

[Most toxin groups have several variants with a range of toxicities. Although known chronic effects are listed, the chronic effects of exposure to cyanotoxins currently (2008) are not well understood. $\mathrm{LD}_{50}$, lethal dose required to kill half of the members of a tested population; $\mu \mathrm{g} / \mathrm{kg}$, micrograms per kilogram of body weight; -, no data available; >, greater than]

\begin{tabular}{|c|c|c|c|c|}
\hline Class & Toxin & $\begin{array}{l}\text { Toxicity } \\
\left(\text { LD }_{50}\right)\end{array}$ & Acute effects & Chronic effects \\
\hline \multirow[t]{3}{*}{ Neurotoxins } & Anatoxins & $20-250 \mu \mathrm{g} / \mathrm{kg}$ & $\begin{array}{l}\text { Seizure, paralysis, respiratory failure, } \\
\text { death }\end{array}$ & unknown \\
\hline & Saxitoxins ${ }^{1}$ & $10 \mu \mathrm{g} / \mathrm{kg}$ & $\begin{array}{l}\text { Tingling or numbness in extremities, } \\
\text { paralysis, respiratory failure, death }\end{array}$ & unknown \\
\hline & $\beta$-N-methylamino-L-alanine (BMAA) & - & - & $\begin{array}{c}\text { neurodegenerative } \\
\text { disease }\end{array}$ \\
\hline \multirow[t]{2}{*}{ Hepatotoxins } & Microcystins & $25->1,000 \mu \mathrm{g} / \mathrm{kg}$ & $\begin{array}{l}\text { Acute hepatoenteritis, shortness of } \\
\text { breath, interhepatic hemorrhage } \\
\text { hemorrhagic shock, heart failure, } \\
\text { death }\end{array}$ & $\begin{array}{l}\text { chronic liver injury, } \\
\text { tumor promoter }\end{array}$ \\
\hline & Nodularins ${ }^{2}$ & $50 \mu \mathrm{g} / \mathrm{kg}$ & Similar to microcystins & tumor promoter \\
\hline \multirow[t]{3}{*}{ Dermatoxins } & Lyngbyatoxins & $300 \mu \mathrm{g} / \mathrm{kg}$ & Severe dermatitis, gastroenteritis & tumor promoter \\
\hline & Aplysiatoxins & $300 \mu \mathrm{g} / \mathrm{kg}$ & Severe dermatitis, gastroenteritis & tumor promoter \\
\hline & Lipopolysaccharides & - & Dermatitis, gastroenteritis & unknown \\
\hline
\end{tabular}

${ }^{1}$ Also known as paralytic shellfish poisons (PSPs).

${ }^{2}$ To date, nodularins have only been detected in brackish waters.

Sources: Chorus and Bartram (1999), Falconer and Humpage (2006), and Stewart and others (2006).

in aquatic environments (Wnorowski, 1992; Rashash and others, 1996; Watson, 2003; Zaitlin and others, 2003; Taylor and others, 2005; Zaitlin and Watson, 2006).

The actinomycetes bacteria are difficult to adequately sample, identify, and measure. Like cyanobacteria, the actinomycetes may produce geosmin and MIB simultaneously, but production is strain specific (Wnorowski, 1992; Watson, 2003; Zaitlin and others, 2003; Zaitlin and Watson, 2006). Total actinomycetes, rather than identification at the genera or strain level, typically are measured. Strain isolation and culture are required to conclusively determine actinomycetes production of geosmin and/or MIB.

\section{Detection of Cyanobacterial Toxins and Taste- and-Odor Compounds}

A variety of analytical techniques exist to aid in the determination of cyanobacterial toxins (Chorus and Bartram, 1999; Nicholson and Burch, 2001; Fastner and others, 2002; Hawkins and others, 2005; Msagati and others, 2006; Nicholson and others, 2007; Osswald and others, 2007). Techniques include bioassays such as enzyme-linked immunosorbent assays (ELISA) (Metcalf and Codd, 2003), protein phosphatase inhibition assays (PPIA), neurotransmitter inhibition assays (acetylcholinesterase inhibition) (Devic and others, 2002), radioassays (Llewellyn and others, 2001), gas chromatography flame ionization detection (GC-FID), mass spectrometry (GC/MS) (Edwards and others, 1992), liquid chromatography (LC) coupled with ultraviolet-visible spectrometry (LC/UV-Vis) (Welker and others, 2002; Barco and others, 2005), fluorescence (LC/Fluorescence), mass spectrometry (LC/MS) (Dell'Aversano and others, 2004), tandem mass spectrometry (LC/MS/MS) (Dahlman and others, 2003; Spoof and others, 2003), and ion trap mass spectrometry (LC/ITMS). Other techniques have been utilized but are not encountered as frequently or are not well suited for quantitative work (Chorus and Bartram, 1999).

Relative advantages and disadvantages of common analytical techniques utilized for analysis of cyanobacterial toxins and taste-and-odor compounds are shown in table 3. Bioassays typically are easy to learn and use, and relatively cost effective when used as a screening tool or, when appropriate, for toxicity assessment (Chorus and Bartram, 1999; Msagati and others, 2006); however, cross-reactivity can lead to a lack of specificity for the target analyte(s) (Metcalf and others, 2002). 
Table 3. Relative advantages and disadvantages of common analytical techniques utilized for analysis of cyanobacterial toxins and taste-and-odor compounds.

\begin{tabular}{|c|c|c|}
\hline Analytical techniques & Advantages & Disadvantages \\
\hline Enzyme-Linked Immunosorbent Assay (ELISA) & Relatively easy to use & Data interpretation can be difficult \\
\hline Inhibition Assays & $\begin{array}{l}\text { Cost per analyses lowest of } \\
\text { all techniques }\end{array}$ & $\begin{array}{l}\text { Inhibition assays and radioassays not } \\
\text { always available }\end{array}$ \\
\hline \multirow[t]{3}{*}{ Radioassays } & $\begin{array}{l}\text { Can be useful as screening } \\
\text { tools }\end{array}$ & $\begin{array}{l}\text { Bioassays frequently possess some } \\
\text { reactivity towards compounds other } \\
\text { than the intended target }\end{array}$ \\
\hline & Can indicate toxicity in some cases & $\begin{array}{l}\text { Radioassays require permits to work with } \\
\text { radioisotopes }\end{array}$ \\
\hline & & $\begin{array}{l}\text { Research objectives may require a } \\
\text { chromatographic technique for } \\
\text { compound specific quantitation }\end{array}$ \\
\hline \multirow[t]{3}{*}{ Mass Spectrometry (GC/MS) } & Cost per analyses intermediate & $\begin{array}{l}\text { Not all compounds amenable to } \\
\text { derivitization }\end{array}$ \\
\hline & $\begin{array}{l}\text { Compound identification by GC/MS is } \\
\text { superior to GC/FID }\end{array}$ & GC/FID may require further confirmation \\
\hline & & $\begin{array}{l}\text { Sample concentration techniques may be } \\
\text { necessary }\end{array}$ \\
\hline \multicolumn{3}{|c|}{ Liquid Chromatography (LC) } \\
\hline Ultraviolet-Visible (LC/UV-Vis) & Derivitization typically not necessary & Matrix effects can be substantial \\
\hline Fluorescence (LC/Fluorescence) & Compound specific & Cost per sample most expensive \\
\hline Ion Trap Mass Spectrometry (LC/ITMS) & $\begin{array}{l}\text { Compound identification is superior by } \\
\text { LC/MS/MS or LC/ITMS }\end{array}$ & \\
\hline
\end{tabular}

If toxin-specific information is required, the chromatographic techniques are more appropriate, but the cost is greater per sample in comparison to bioassays. Researchers are utilizing multi-toxin LC/MS/MS methods more frequently because of the ability to distinguish a larger variety of individual toxins more readily, and avoid the derivitization that would be required for any GC-based technique. LC/MS and LC/MS/MS can suffer from matrix effects more than the other techniques, but it is possible to compensate for this problem through standard addition or isotope dilution (Vogeser and Parhofer, 2007; Lanckmans and others, 2008). However, isotope dilution (Vogeser and Parhofer, 2007) currently (2008) is not an option because labeled toxins are not commercially available.
Fewer analytical options are available for determination of taste-and-odor compounds. Closed- and open-loop stripping techniques combined with GC-FID or GC-MS have been used previously, but the stripping techniques largely have been replaced by solid-phase microextraction (SPME) where phase transfer of the semi-volatile compounds to the gas phase is followed by separation and detection by GC/MS. Typical method reporting levels range from 1 to 5 nanograms per liter (ng/L), the lower threshold for human detection of these compounds (Zimmerman and others, 2002; Taylor and others, 2005). Currently (2008), there are no commercially available ELISA's for taste-and-odor analysis sensitive enough to be of practical use. 


\section{Spatial and Temporal Variability of Cyanobacteria and Associated Toxins and Taste-and-Odor Compounds}

The spatial and temporal variability of cyanobacterial populations depends on lake/reservoir hydrology, morphology, geography, water chemistry, and biological interactions. Spatiotemporal occurrence patterns are unique to individual lakes, and generalizations are difficult because of the large degree of variability among lakes. Likewise, a diverse range of physical, chemical, and biological factors may potentially limit algal growth, and no one variable is an unequivocal link to cyanobacterial bloom formation. Long-term patterns in when, where, and under what conditions cyanobacterial blooms typically develop may emerge in lakes that have been studied for several years, or cyanobacterial blooms may only occur sporadically (Reynolds, 1984, 1998; Chorus and Bartram, 1999; Wetzel, 2001; Falconer, 2005). Local knowledge of general lake/reservoir limnology and cyanobacterial bloom occurrence will enhance the ability to select appropriate sampling times and locations to meet study objectives. If historical data are unavailable, initial sampling schedules may be more intensive until general patterns in occurrence begin to emerge (Chorus and Bartram, 1999; Falconer, 2005).

Cyanobacterial toxins and taste-and-odor compounds occur in two different phases: the particulate phase and the dissolved phase. The particulate phase comprises compounds that are maintained intracellularly by the cyanobacteria. Intracellular toxin and taste-and-odor concentrations are strain dependent and may vary by several orders of magnitude between strains. Current (2008) research indicates that spatial and temporal variability in toxin and taste-and-odor concentrations are largely because of changes in cyanobacterial abundance and strain composition rather than changes in intracellular content (Rashash and others, 1996; Orr and Jones, 1998; Chorus, 2001; Long and others, 2001; Oudra and others, 2002). The dissolved phase comprises extracellular compounds that have been released into the water column either actively by healthy cells or passively upon cell lysis and death. Combined, the particulate (intracellular) and dissolved (extracellular) phases comprise total toxin or taste-and-odor concentration (Jones and Korth, 1995; Chorus and Bartram, 1999; Graham and Jones, 2007). Particulate, dissolved, and total toxin and taste-and-odor compound concentrations may all be measured (Graham and Jones, 2007); however, measured total and intracellular concentrations are dependent on the efficacy of extraction methods (Chorus and Bartram, 1999).

Cyanobacterial toxins generally are maintained intracellularly until death and cell lysis. Dissolved toxin concentrations remain low until populations either begin to senesce naturally or are lysed by management practices, such as application of algaecides. Because cyanobacterial toxins typically are maintained intracellularly, toxins generally have a similar spatial distribution as the cyanobacteria (Chorus and Bartram, 1999; Falconer, 2005). Theoretically, the partitioning of cyanobacterial toxins between the particulate and dissolved phases will change with time as population density increases and declines; particulate concentrations will track overall changes in cyanobacterial population density, whereas dissolved concentrations will remain relatively low until population density begins to decline. The general pattern in the temporal distribution of total, particulate, and dissolved cyanobacterial toxin concentrations, with respect to cyanobacterial population density, is illustrated in figure 4. Field observations indicate
Figure 4. Theoretical temporal distribution of total, particulate, and dissolved cyanobacterial toxin concentrations with respect to cyanobacterial population density.

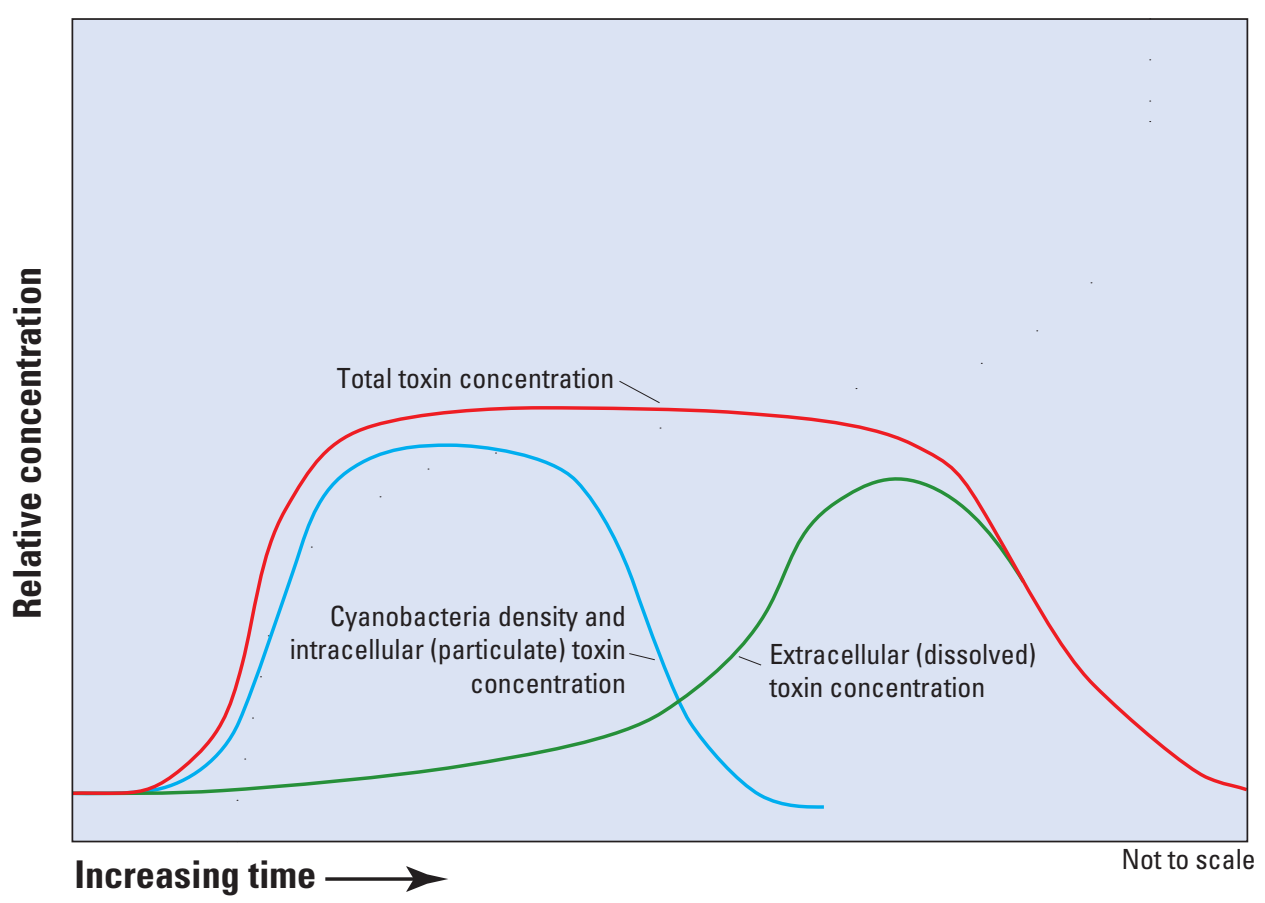


that this pattern occurs in lakes and reservoirs (Jones and Orr, 1994; Heresztyn and others, 1997; Chiswell and others, 1999; Chorus and Bartram, 1999); however, many other patterns also may occur because toxic and non-toxic strains of cyanobacteria can co-occur and will not necessarily have the same population dynamics. The partitioning of taste-andodor compounds between the particulate and dissolved phases is more complex, because healthy cyanobacterial cells may maintain these compounds intracellularly or release them into the environment; therefore, taste-and-odor compounds are not necessarily associated with the cyanobacteria and may or may not have similar spatial distributions (Rashash and others, 1996; Watson, 2003; Taylor and others, 2005).

The environmental fate and transport of cyanobacterial toxins and taste-and-odor compounds under natural lake/reservoir conditions has not been well studied. Available laboratory data indicate that photolysis and biodegradation are the most likely mechanisms for the degradation of cyanobacterial byproducts in lakes and reservoirs (Kiviranta and others, 1991; Stevens and Krieger, 1991; Tsuji and others, 1994; Cousins and others, 1996; Chiswell and others, 1999; Holst and others, 2003; Ou and others, 2005; Kato and others, 2007). Based on field observations, dissolved phase toxins and taste-and-odor compounds may persist for several days to weeks after the decline of a cyanobacterial population (Jones and Orr, 1994; Heresztyn and others, 1997; Chorus and Bartram, 1999). The persistence of toxins and taste-and-odor compounds, coupled with the potential for transport, may lead to spatial or temporal uncoupling of cyanobacteria and their by-products.

\section{Temporal Variability}

Seasonal patterns in cyanobacterial abundance and community composition are affected substantially by temperature, solar irradiance, and nutrient supply. Cyanobacterial populations tend to peak between mid-summer and early fall when water temperatures are at seasonal maxima and nutrient concentrations are at seasonal minima; however, cyanobacteria may remain abundant year round, even in temperate lakes, or peak under ice during winter (Reynolds, 1984, 1998; Chorus and Bartram, 1999; Wetzel, 2001; Falconer, 2005). Cyanobacterial populations also may vary on much shorter time scales (hours or days). Whereas cyanobacterial abundance may increase fairly rapidly (days), vertical migration, entrainment in temporary circulation cells, or wind movement of surface accumulations may change the location of cyanobacteria within the lake/reservoir or water column, but not overall abundance. Knowledge of local conditions, including patterns in circulation, mixing, and prevailing winds, will enhance overall study design and aid in the interpretation of observed changes in cyanobacterial abundance and community structure (Chorus and Bartram, 1999; Falconer, 2005).

\section{Spatial Variability in Lakes and Reservoirs}

Cyanobacterial movement affects distribution in the water column, and wind movement of surface accumulations may have a substantial effect on where cyanobacteria are located within a lake or reservoir; however, the general location of cyanobacteria largely is affected by lake/reservoir hydrology and morphology. Cyanobacterial populations may be evenly distributed throughout a lake or reservoir or have an irregular distribution because of currents and prevailing winds (fig. 5). Statistically significant differences in toxin concentrations have been detected within sampling distances of $10 \mathrm{~m}$ (Carmichael and Gorham, 1981; Lanaras and others, 1989; Kotak and others, 2000), although extreme spatial variation is not necessarily typical (Jungmann and others, 1996). Spatial distribution may change rapidly because of changing hydrologic conditions such as new circulation patterns or inflow events. After heavy rains cyanobacteria in the reservoir shown in figure 5 were washed from up-reservoir areas into the main body of the reservoir. The cyanobacterial population in this case was restricted to the old river channel (near the tree line). In larger lakes or reservoirs certain areas (shallow bays and coves, sites directly affected by nutrient rich inflows, or structures that affect flow such as dikes, piers, or potentially larger intake towers) may be more prone to the development of cyanobacterial blooms and surface accumulations. These isolated blooms may remain localized or spread throughout the lake because of inflow events or circulation patterns (Reynolds, 1984; Chorus and Bartram, 1999; Wetzel, 2001; Falconer, 2005). Some knowledge of the distribution of cyanobacteria, as affected by hydrology, morphology, and typical conditions, throughout a lake is required before the development of toxin and tasteand-odor studies. The sites selected for study will depend on the overall study objectives (Chorus and Bartram, 1999; Falconer, 2005).

\section{Spatial Variability in the Water Column}

The ability of many toxin and taste-and-odor producing cyanobacteria to control their position in the water column needs special consideration when sampling for these compounds. The vertical distribution of cyanobacteria may vary widely for relatively short (hours or days) periods of time (Reynolds, 1984; Chorus and Bartram, 1999; Falconer, 2005). Sample location in the water column relative to cyanobacterial distribution may have a substantial affect on results. For example, if cyanobacteria are maintaining a position at depth in the water column, and surface samples are collected, toxins or taste-and-odor compounds may not be detected even when present. There are six general water column distributions of cyanobacteria; detailed descriptions and occurrence information are given in figures 6 and 7: 


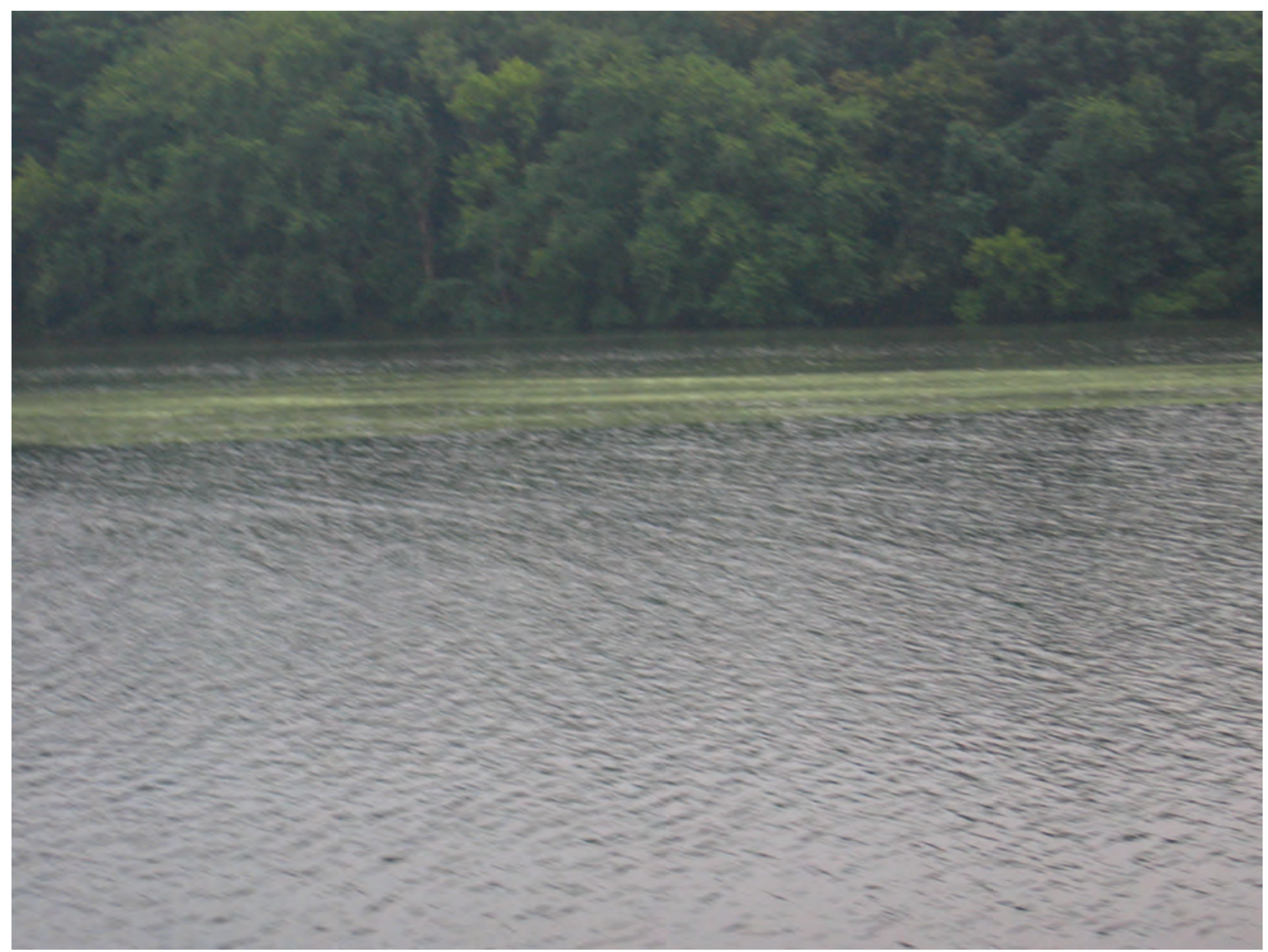

Figure 5. Example of spatial variability of cyanobacteria within a reservoir.

1. Shoreline, near-shore, or open-water surface accumulations and scums (fig. $6 A$ and fig. $7 A$ ). Surface accumulations and scums are of greatest concern for recreational exposure to high concentrations of cyanobacterial toxins.

2. Even distribution throughout the photic zone or epilimnion (fig. $6 B$ and fig. $7 B$ ).

3. Specific depth in the photic zone (fig. $6 C$ and fig $7 C$ ). In shallow lakes where light penetrates to the bottom (photic depth equals maximum depth), cyanobacteria may be located on or near the bottom.

4. Metalimnetic bloom (fig. $6 D$, fig. $7 D$, fig. 8 ). This is a special case of a population maintaining a specific depth in the photic zone. Metalimnetic blooms are evident by sharp increases in oxygen at depth, typically near the interface of the epilimnion and metalimnion (figs. 1 and 8). Metalimnetic blooms are of particular concern in drinking-water supplies because the populations are not visibly evident and may be located at the same depth as the drinking-water intake.
5. Even distribution throughout the water column (fig. $6 E$ and fig. $7 E$ ).

6. Under ice (fig. $6 F$ and fig. $7 F$ ).

The distribution of cyanobacteria in the water column often can be determined by a combination of visual assessment, light profiles to determine photic depth, and temperature and dissolved oxygen profiles to determine stratification, mixed depth, and presence of a metalimnetic population (figs. 6-8). Cyanobacteria often will maintain a position in the photic zone, regardless of mixed depth (Reynolds and Walsby, 1975; Reynolds, 1987; Chorus and Bartram, 1999; Wetzel, 2001; Falconer, 2005; Graham and others, 2006); therefore, if cyanobacterial distribution in the water column cannot be conclusively determined, an integrated photic zone sample will likely be fairly representative.

Once toxins and taste-and-odor compounds are released by cyanobacteria into the dissolved phase, they will become uniformly distributed throughout the mixed layer in which they are released; this typically is a rapid process, but large localized concentrations may develop in hydraulically isolated areas such as coves (Jones and Orr, 1994). Generally, 


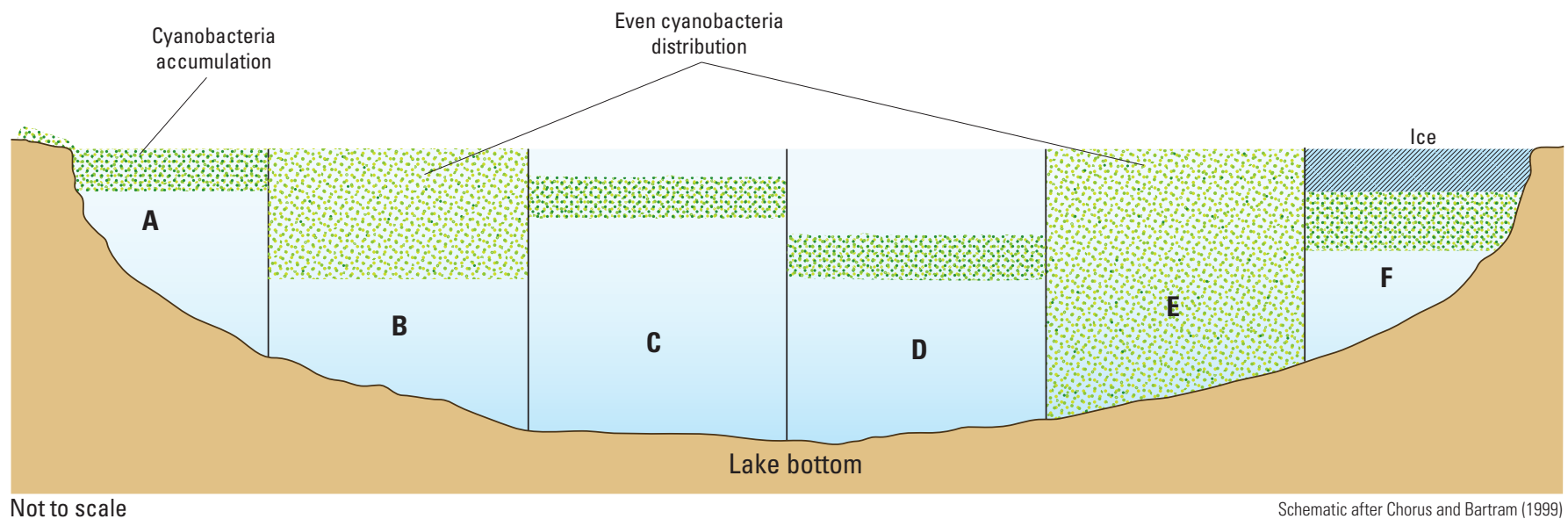

\section{EXPLANATION}

Potential water column distributions of cyanobacteria

A Shoreline, near-shore, and open water accumulations and scums

B Even distribution throughout the photic zone or epilimnion

C Specific depth in the photic zone

D Metalimnetic bloom (special case of C)

E Even distribution throughout the water column

F Under ice bloom

Figure 6. Potential water column distributions of cyanobacteria.

the distribution of dissolved compounds in the water column will depend on the layer in which the cyanobacteria were located when the compounds were released. In stratified lakes, cyanobacteria most likely are in the epilimnion or, less frequently, the metalimnion. Dissolved toxin and taste-and-odor samples usually can be collected from the same water column location as samples for intracellular (particulate) analysis (Chorus and Bartram, 1999; Falconer, 2005).

\section{Common Study Types, Objectives, Designs, and Approaches for Studies of Cyanobacteria and Associated Toxins and Taste-and-Odor Compounds}

Averett and Schroder (1994) describe three general types of surface-water-quality studies: reconnaissance studies, monitoring studies, and interpretive studies. These study types do not have well-defined boundaries, and often there is overlap between types as study objectives and designs are developed. Cyanobacterial toxin and taste-and-odor studies are discussed with respect to these three study types. The keys to a well designed study include using the scientific method, a well-defined problem, clear objectives, and an appropriate approach. Study objectives will dictate what variables need to be measured, and when, where, and how samples will be collected. More detail on the general types of surface-waterquality studies and the fundamentals of study design are given in Averett and Schroder (1994).

The study of cyanobacterial toxins and taste-and-odor compounds is an active area of developing research, but many fundamental questions remain about the occurrence, environmental causes, and ecological consequences of these compounds (Chorus, 2001). Current (2008) studies include: reconnaissance studies to evaluate the occurrence, distribution, and concentration of cyanobacterial toxins and taste-and-odor compounds; monitoring studies to determine the potential for human health risks and taste-and-odor events associated with cyanobacterial toxins and taste-and-odor compounds; and a range of interpretive studies. Interpretive studies include: evaluation of the physical, chemical, and biological factors affecting cyanobacterial and taste-and-odor compound occurrence and concentration and the development of empirical models; determination of the environmental fate and transport (including persistence, degradation, and movement in the environment and among ecosystem compartments) of cyanobacterial toxins and taste-and-odor compounds; and assessment of the toxicological effects of cyanobacterial toxins and tasteand-odor compounds on aquatic and terrestrial organisms and overall ecosystem function and health. There are many types of studies that can be conducted within these general topical 


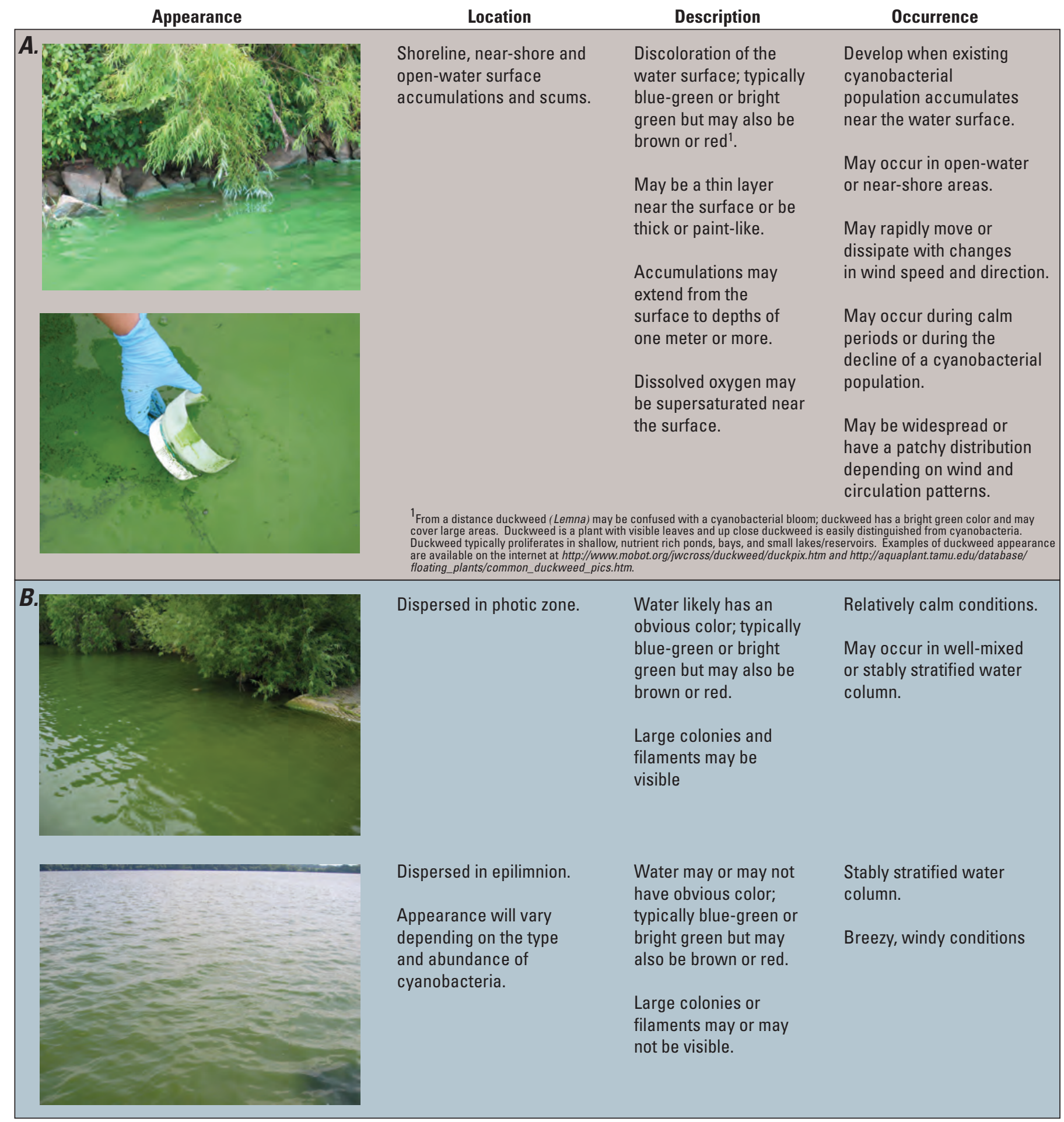

All photographs by J.L. Graham, USGS Lawrence, Kansas, with the exception of : $\boldsymbol{E}$., courtesy of Kansas Department of Health and Environment, and $\boldsymbol{F}$, courtesy of an anonymous photographer.

Figure 7. Appearance, location, description, and occurrence of the potential water column distributions of cyanobacteria. 


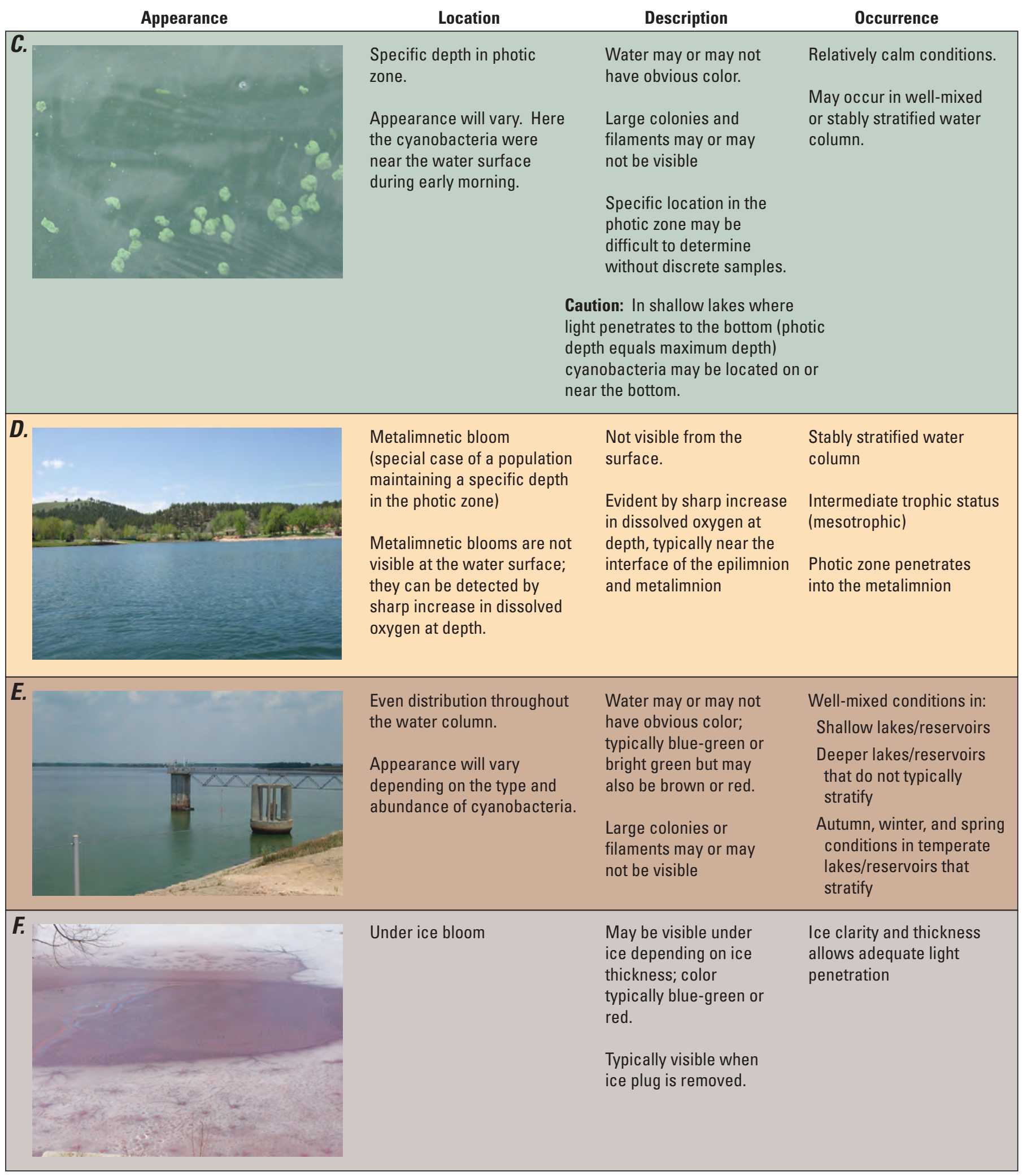

All photographs by J.L. Graham, USGS Lawrence, Kansas, with the exception of : $\boldsymbol{E}$., courtesy of Kansas Department of Health and Environment, and $\boldsymbol{F}$, courtesy of an anonymous photographer.

Figure 7. Appearance, location, description, and occurrence of the potential water column distributions of cyanobacteria.-Continued 


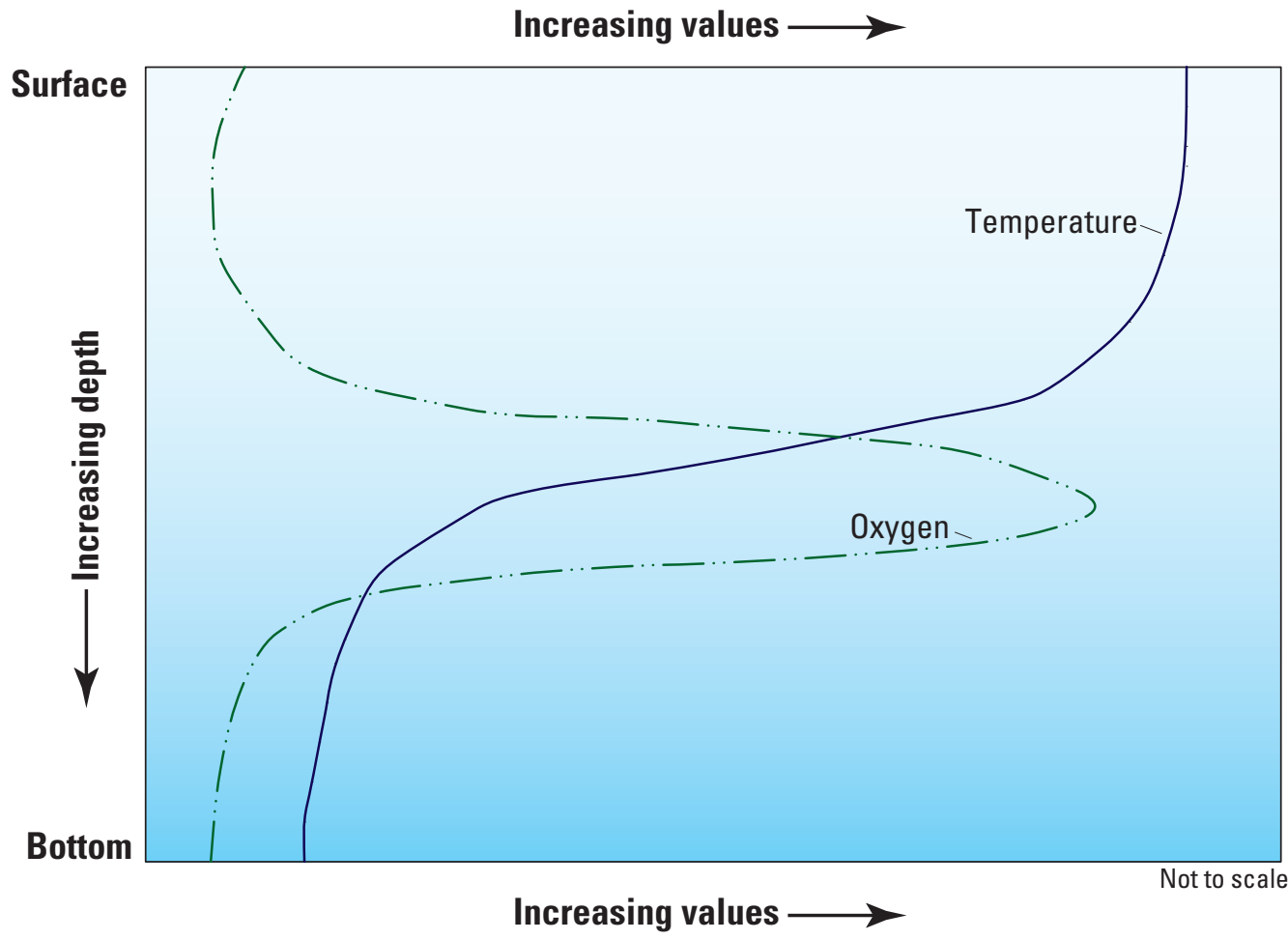

Figure 8. Graphical representation of the temperature and oxygen gradients that will develop in the water column when a metalimnetic cyanobacterial bloom is present. areas. This section is not intended to provide a comprehensive list of all possible types of studies and research objectives for lake or reservoir studies on toxins and taste-and-odor compounds; rather, it is intended to illustrate how the information presented on the spatial and temporal variability of cyanobacteria and cyanobacterial blooms can be used to guide and enhance the design of field studies. The examples presented cover many, but not all, of the possible objectives, sampling frequencies, site locations, and collection methods.

General study objectives and guidelines on when, where, and how to sample are presented for reconnaissance, monitoring, and interpretive studies. Special consideration needs to be given to the distribution of cyanobacteria in the study lake or reservoir and water column when deciding where and how to collect samples; sample location needs to be relevant to where the cyanobacterial community is located. Ultimately, sampling approach and site selection will depend on specific study objectives. Sampling frequency, site location, time of day samples are collected, and type of samples collected need to be carefully considered with respect to study objectives.

\section{Reconnaissance Studies}

Reconnaissance studies typically are conducted to assess the occurrence and concentration of cyanobacteria and associated toxins and taste-and-odor compounds. Studies may focus on spatial and/or temporal variability at a range of scales, from single systems to states or regions. Studies of lakes or reservoirs used for recreation typically emphasize cyanobacterial toxins, whereas studies of drinking-water supply lakes or reservoirs may emphasize taste-and-odor compounds and toxins. General study objectives and guidelines describing when, where, and how samples typically are collected for reconnaissance studies are presented in table 4. An example of a study design, approach, and field form for a reconnaissance study is given in Appendix 1.

\section{Monitoring Studies for Public Health and Drinking Water Treatment}

Monitoring studies typically are conducted to determine the concentration of cyanobacterial toxins and taste-and-odor compounds in areas where exposure is most likely to occur. Recreational areas are monitored for cyanobacterial toxins to assess human health risks; results often are used to make decisions about posting warnings and closing recreational areas. Drinking-water intakes are monitored for taste-and-odor compounds and/or toxins to assess the potential for taste-andodor events and human health risks; results often are used to guide drinking-water treatment processes. Guidelines describing when, where, and how samples typically are collected for monitoring studies are presented in table 5. An example of a study design, approach, and field form for a monitoring study is given in Appendix 2.

\section{Interpretive Studies}

Interpretive studies typically are conducted to assess the processes that affect the spatial and temporal 
distribution and abundance of cyanobacterial toxins and tasteand-odor compounds. Interpretive studies may include, but are not limited to, the assessment of the physical, chemical, and biological factors affecting occurrence and concentration, environmental fate and transport studies, and toxicological studies. Studies assessing the environmental factors affecting occurrence and concentration often are focused on developing empirical models (Mau and others, 2004; Christensen and others, 2006). Several years of study, with a range of hydrologic and meteorologic conditions, often are required before true patterns begin to emerge. Long-term studies are required to develop methods for early detection, such as real-time estimation of the occurrence or concentration of cyanobacterial toxins and taste-and-odor compounds, and models predicting when events are likely to occur. Reliable tools for early detection and predictive models will allow resource managers time to respond more effectively to potentially harmful conditions. General study objectives and guidelines describing when, where, and how samples typically are collected for studies assessing the environmental factors affecting the occurrence and concentration of cyanobacterial by-products are presented in table 6. An example of a study design, approach, and field form for an interpretive study is given in Appendix 3.

Fate and transport and toxicological studies are crucial to the overall understanding of environmental and public health risks associated with cyanobacterial toxins and taste-and-odor compounds. These studies frequently collect water-column samples from lakes and reservoirs; they often also require samples from sediments, benthic organisms, and tissues. Few data are available regarding the partitioning of cyanobacterial toxins and taste-and-odor compounds in these alternative ecosystem compartments; sampling protocols and analytical methods either have not been developed or currently (2008) are under development. Discussion of how to collect these types of samples is beyond the scope of this chapter and examples are not provided for fate and transport and toxicological studies.

\section{General Guidelines for Sampling}

Three general types of water-quality samples are collected from lakes and reservoirs: surface samples, discretedepth samples, and depth-integrated samples. Depth-integrated samples may encompass the photic zone, epilimnion, metalimnion, hypolimnion, entire water column, or other layers of interest depending on study objectives. The types of samplers commonly used to collect each type of sample are listed in table 7. Detailed descriptions of the samplers and proper uses are presented in Britton and Greeson (1987), the USGS National Field Manual (NFM) chapters 2 (Lane and others, 2003) and 4 (U.S. Geological Survey, 2006), and Standard Methods Sections 1060 and 10200 (Clesceri and others, 1998). Because toxins and taste-and-odor compounds are organic compounds, the samplers and churns used to collect and composite samples need to be made of fluorocarbon polymers such as Teflon (Lane and others, 2003).

Some cyanobacterial colonies or filaments may exceed the maximum particle size (250 micrometers) recommended for use of a churn splitter (Lane and others, 2003); however, particle size does not matter when dealing with algae. There are no settling issues with algae like there are with sediments. Churning velocity will maintain all algal size classes within the sample. Likewise, churning velocity also will maintain all cyanobacterial size classes within a sample regardless of buoyancy. Although some colonies and filaments may break apart during the churning process, individual cell integrity should not be affected by churning. Use of churns is inappropriate when collecting samples from thick accumulations with little water content.

For each sample type, a single grab sample may be collected or multiple grab samples may be composited into a churn. Whether a single grab or composite sample is collected will depend on study objectives and the volume of water needed. How samples are composited also will depend on study objectives. If specific locations are of interest, composites may be collected from the same depth and location until the required volume of water has been acquired; if general or average conditions are of interest, composites may be composed of samples collected from multiple depths in the water column or multiple locations in the lake or reservoir. Composite samples are more representative of overall conditions; however, because of the generally irregular distribution of phytoplankton communities, concentrations of toxins and taste-and-odor compounds may be diluted (Clesceri and others, 1998).

\section{Surface Samples}

If surface samples are collected in open-water areas, samples need to be collected $0.5-1.0 \mathrm{~m}$ below the surface to avoid substances that are trapped in the surface film and may affect results (Clesceri and others, 1998). If surface accumulations or scums are being sampled, then collection at the water surface is appropriate. Study objectives need to be considered when determining how to sample surface accumulations and scums because cyanobacterial density may vary widely across the area of accumulation. If a general idea of maximum toxin and/or taste-and-odor compound concentration is desired, a sample collected from the thickest part of the accumulation or scum is adequate (Chorus and Bartram, 1999). If an average concentration in the accumulation or scum is desired, multiple samples can be collected throughout the area and composited. A grid or transect approach often is used for this type of collection (Clesceri and others, 1998). The number of samples used for a composite will depend on study objectives and the size of the accumulation or scum. If information on spatial heterogeneity is desired, samples need to be collected throughout the accumulation or scum area, but not composited (Clesceri and others, 1998; Chorus and Bartram, 1999). 


\section{Discrete-Depth Samples}

Discrete-depth samples typically are collected when the location of the cyanobacterial community is known, there is a structure of interest at depth (such as a drinking water intake), or when the vertical water column distribution of the cyanobacterial community and associated toxins and tasteand-odor compounds is of interest.

\section{Depth-Integrated Samples}

Depth-integrated samples typically are collected when the cyanobacterial community is evenly distributed throughout a layer of interest, or the interest is in dissolved concentrations only. An exception may be when the distribution of cyanobacteria in the water column can not be determined; in this case an integrated photic zone sample will be generally representative. There are two types of depth-integrated samples: continuous and discontinuous. Continuous samples incorporate the entire depth of interest and are collected using pumps or bailers. Several continuous samples may be composited to obtain the necessary sample volume. Discontinuous samples do not incorporate the entire depth of interest, and are collected using Kemmerer or Van Dorn samplers, although the percent of the water column represented can be increased by using a vertical sampler rather than a horizontal sampler (table 7; Lane and others, 2003; U.S. Geological Survey, 2006). A depthintegrated sample may be obtained by collecting and compositing several discontinuous samples from several depths within the layer of interest. If discontinuous samples are collected, sample intervals need to be equal (for example every meter within the photic zone) (Chorus and Bartram, 1999; Clesceri and others, 1998).

\section{Quality Control}

Quality-control samples, such as blanks, splits, and replicates, are an integral component of well designed water-quality studies and are used to assess variability caused by sample collection, processing, shipping, and handling. Quality-assurance plans and the types of quality-control samples collected will depend on study design and objectives. Detailed information on how to develop quality-assurance plans and descriptions of the different types of quality-control samples are discussed elsewhere (Friedman and Erdmann, 1982; Shampine and others, 1992; U.S. Geological Survey, 2006).

Cyanobacterial communities tend to have an irregular distribution within the water column and throughout a lake or reservoir; therefore, concurrent and sequential field replicates (U.S. Geological Survey, 2006) to assess sampling variability are particularly important in studies of cyanobacterial toxins and taste-and-odor compounds. Methods for the extraction and analysis of toxins and taste-and-odor compounds are evolving rapidly and currently (2008) are not consistent among laboratories. Split samples (U.S. Geological Survey, 2006) to assess intra- and inter-laboratory variability in extraction and analysis are useful.

\section{Sample Handling, Preparation, Processing, and Shipping for Analyses}

There are several cyanobacterial toxins and taste-andodor compounds that commonly are measured including the toxins microcystin, cylindrospermopsin, anatoxin, and saxitoxin and the taste-and-odor compounds geosmin and MIB. BMAA is not characterized well enough at this time to provide guidelines on sampling procedures or sample handling. A key decision when designing toxin and taste-and-odor studies is whether total, particulate, or dissolved concentrations will be analyzed. Sample handling, preparation, and processing will partly be determined by whether total, particulate, and/or dissolved compounds are measured. Another important determinant is the instructions provided by the laboratory conducting the analyses. Laboratories may request whole water samples and do all processing in house; others will provide specific instructions including the type of sample bottle to use, and yet others will provide instructions as well as sample bottles and preservatives. There also may be restrictions on delivery days that may affect analyses on unpreserved samples. Clear communication with the laboratories performing the analyses is required to ensure sample analyses will provide the desired results. Although handling, preparation, processing, and shipping largely may be determined by the analyzing laboratory, general guidelines are provided below.

\section{Sample Handling}

Ideally, all samples are processed on site. If samples need to be transported before processing, they are placed on ice in the dark because heat and light may cause degradation of cyanobacterial cell integrity, toxins, and taste-and-odor compounds. All samples need to be processed the same day they are collected.

Many cyanobacterial toxins do not degrade when frozen, and samples may be stored in a freezer for several months or years (Chorus and Bartram, 1999). Keep in mind that if whole water samples are frozen, cyanobacterial cells will lyse and release intracellular toxins; freezing and thawing whole water samples frequently is used to determine total toxin concentration (Gjølme and Utkilen, 1994; Chorus and Bartram, 1999; Johnston and Jacoby, 2003; Graham and Jones, 2007). Tasteand-odor samples generally are not frozen.

\section{Processing Toxin and Taste-and-Odor Samples}

Total Concentration Samples-Total samples measure both particulate (intracellular) and dissolved (extracellular) phases of cyanobacterial toxins and/or taste-and-odor compounds. Total concentrations are measured directly by 
Table 4. General study objectives and guidelines describing when, where, and how samples typically are collected for reconnaissance studies.

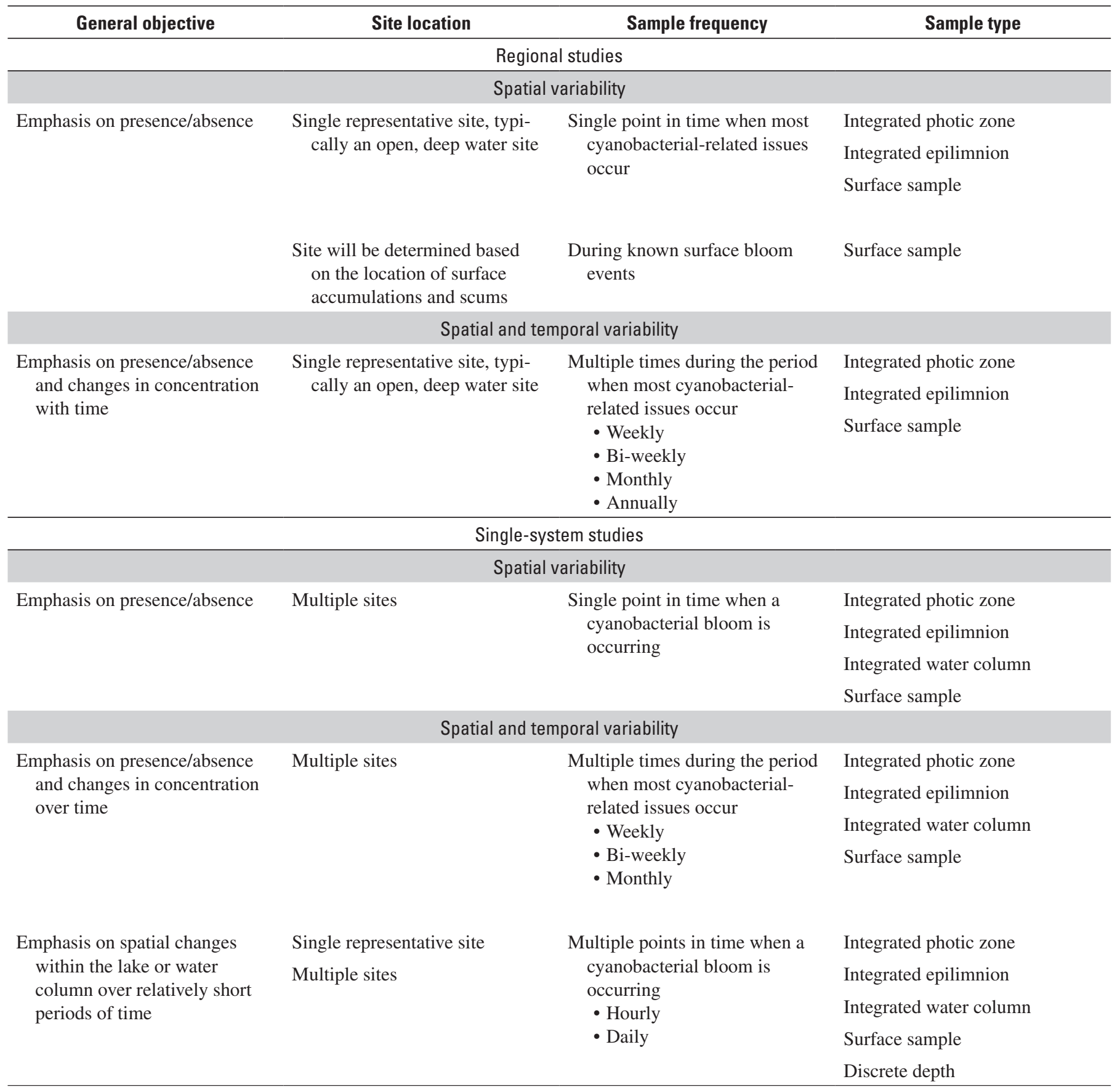

Sources: Chorus and Bartram (1999), Falconer (2005), and Wetzel and Likens (2000). 
Table 5. General study objectives and guidelines describing when, where, and how samples typically are collected for monitoring studies.

\begin{tabular}{|c|c|c|c|}
\hline General objective & Site location & Sample frequency & Sample type \\
\hline Recreational areas & $\begin{array}{l}\text { Beaches } \\
\text { Open water areas used for full- } \\
\text { body contact recreation } \\
\text { Bay or cove areas used for full- } \\
\text { body contact recreation } \\
\text { Public access sites }\end{array}$ & $\begin{array}{l}\text { Routine basis during periods of } \\
\text { peak recreational use } \\
\text { - Daily } \\
\text { - Weekly }\end{array}$ & $\begin{array}{l}\text { Surface sample } \\
\text { Integrated photic zone }\end{array}$ \\
\hline Drinking-water supplies & $\begin{array}{l}\text { Location relevant to the drinking- } \\
\text { water intake(s) }\end{array}$ & $\begin{array}{l}\text { Routine basis } \\
\text { - Daily } \\
\text { - Weekly } \\
\text { During periods when events have } \\
\text { historically occurred } \\
\text { During events }\end{array}$ & $\begin{array}{l}\text { Discrete depth } \\
\text { Integrated photic zone } \\
\text { Integrated epilimnion } \\
\text { Integrated water column }\end{array}$ \\
\hline
\end{tabular}

Sources: Chorus and Bartram (1999), Falconer (2005), and Wetzel and Likens (2000).

Table 6. General study objectives and guidelines describing when, where, and how samples typically are collected for interpretive studies assessing the physical, chemical, and biological factors affecting the occurrence and concentration of cyanobacteria and associated toxins and taste-and-odor compounds.

\begin{tabular}{|c|c|c|c|}
\hline General objective & Site location & Sample frequency & Sample type \\
\hline \multirow{7}{*}{$\begin{array}{l}\text { Environmental factors } \\
\text { influencing spatial and/or } \\
\text { temporal occurrence } \\
\text { Real-time estimation of } \\
\text { occurrence/concentration } \\
\text { Predictive models }\end{array}$} & \multirow{4}{*}{$\begin{array}{l}\text { Single representative site, } \\
\text { typically an open, deep } \\
\text { water site } \\
\text { - Sites for drinking-water } \\
\text { studies are typically } \\
\text { located near intakes }\end{array}$} & \multirow{5}{*}{$\begin{array}{l}\text { Routine basis } \\
\text { - Weekly } \\
\text { - Bi-weekly } \\
\text { - Monthly }\end{array}$} & \multirow{4}{*}{$\begin{array}{l}\text { Integrated photic zone } \\
\text { Integrated epilimnion } \\
\text { Integrated water column } \\
\text { Discrete depth }\end{array}$} \\
\hline & & & \\
\hline & & & \\
\hline & & & \\
\hline & \multicolumn{2}{|l|}{$\begin{array}{l}\text { Multiple sites } \\
\text { - Sites where cyanobacterial } \\
\text { blooms are known to } \\
\text { initiate } \\
\text { - Sites where cyanobacteria } \\
\text { are typically abundant } \\
\text { - Inflow sites }{ }^{1}\end{array}$} & \\
\hline & \multirow{2}{*}{$\begin{array}{l}\text { Sites where surface accumula- } \\
\text { tions/scums are located }\end{array}$} & Event samples & \multirow[t]{2}{*}{ Surface sample } \\
\hline & & $\begin{array}{l}\text { Sampling plans need to be } \\
\text { flexible enough to respond to } \\
\text { events }\end{array}$ & \\
\hline
\end{tabular}

Sources: Chorus and Bartram (1999), Christensen and others (2006), Falconer (2005), and Wetzel and Likens (2000).

${ }^{1}$ Monitoring of major inflows is essential in the development of predictive models and beneficial in the development of models for real-time estimation of occurrence/concentration. Standard USGS protocols for sampling streams and rivers should be used when sampling inflows (U.S. Geological Survey, 2006). Cyanobacterial samples and samples for toxin and taste-and-odor analysis may or may not be analyzed at inflow sites, depending on conditions; however, actinomycetes samples need to be collected. 
Table 7. Samplers commonly used to collect surface, discrete depth, and depth integrated samples in lakes and reservoirs.

[Descriptive information on the samplers as well as appropriate use is available in Britton and Greeson, 1987, U.S. Geological Survey National Field Manual chapters 2 (Lane and others, 2003) and 4 (U.S. Geological Survey, 2006), and Standard Methods Sections 1060 and 10200 (Clesceri and others, 1998).]

\begin{tabular}{|c|c|}
\hline Sample type & Sampler \\
\hline \multirow[t]{2}{*}{ Surface } & Hand-held open mouth bottle sampler \\
\hline & Weighted bottle sampler (US WBH-96) \\
\hline \multirow[t]{3}{*}{ Discrete depth } & Kemmerer Bottle \\
\hline & Van Dorn Bottle-horizontal or vertical \\
\hline & Pump_diaphragm or peristaltic \\
\hline \multirow[t]{4}{*}{ Depth integrated } & Kemmerer Bottle \\
\hline & Van Dorn Bottle-vertical \\
\hline & Pump—diaphragm or peristaltic \\
\hline & Bailer \\
\hline
\end{tabular}

rupturing cyanobacterial cells and releasing the compounds into solution (note that total concentrations are dependent on the efficacy of extraction techniques) (fig. 9). Whole water samples are typically collected for total concentration analysis in 500- to 1,000-mL bottles, commonly high-density polyethylene (HDPE) plastic or amber glass. Bottle type and volume will depend on the laboratory doing the analysis. Total concentrations also may be measured indirectly by summing particulate and dissolved concentrations (Chorus and Bartram, 1999; Graham and Jones, 2007).

Particulate Concentration Samples-Particulate samples measure only the intracellular phase of cyanobacterial toxins and/or taste-and-odor compounds. Particulate concentrations are measured directly by concentrating cyanobacteria from a known volume of water onto a filter (fig. 9) (Chorus and Bartram, 1999). The filter is extracted prior to analysis (note that particulate concentrations are dependent on the efficacy of extraction techniques). Samples for particulate analysis are collected on 0.7-micrometer $(\mu \mathrm{m})$ glass fiber filters, and processed in the same manner as chlorophyll samples; processes are described in NFM chapter 7.4 (Hambrook Berkman and Canova, 2007). Because toxins and taste-and-odor compounds are organic compounds, glass or metal filter funnels and glass receiving flasks need to be used. When filtering, remember to accurately measure and record the filtered volume. Particulate concentrations also may be measured indirectly by taking the difference between total and dissolved concentrations (Chorus and Bartram, 1999; Graham and Jones, 2007).

Dissolved Concentration Samples-Dissolved samples measure only the extracellular phase of cyanobacterial toxins and/or taste-and-odor compounds. Filtrate from $0.7-\mu \mathrm{m}$ glass fiber filters is collected for dissolved toxin analysis (fig. 9). A glass or metal filter funnel and glass receiving flask are used for the filtration process. Filtrate from preparation of particulate toxin samples or chlorophyll samples may be used. Again, HDPE plastic and amber glass bottles are typically used (Chorus and Bartram, 1999; Graham and Jones, 2007). Bottle type and volume will depend on the laboratory doing the analysis. Analysis of taste-and-odor compounds most commonly is performed on dissolved samples, but total and particulate concentrations also are determined regularly (van der Ploeg and others, 1992; Wnorowski and Scott, 1992; Jones and Korth, 1995; Yen and others, 2007).

Toxin and taste-and-odor concentrations typically are expressed volumetrically as micrograms per liter $(\mu \mathrm{g} / \mathrm{L})$ because volumetric concentrations are easily related to drinking water and recreational guideline values. Concentrations also may be expressed gravimetrically as micrograms per gram dry weight ( $\mu \mathrm{g} / \mathrm{g}$ dry weight). To estimate dry weight, an additional sample can be prepared as for particulate analysis and weighed after desiccation or lyophilization. Particulate concentrations may then be expressed either volumetrically or gravimetrically. Gravimetric concentrations need to be interpreted with caution. When collected from dense accumulations of cyanobacteria, gravimetric expression of toxin or taste-andodor concentration often is directly related to cyanobacterial abundance; however, when collected in open-water areas, dry weight will incorporate all suspended particulates including other phytoplankton, zooplankton, and sediment (Chorus and Bartram, 1999).

\section{Processing Cyanobacterial (Phytoplankton) Samples}

Whole water samples are collected for cyanobacterial community composition analysis, abundance (cells or natural units per milliliter or liter), and biovolume (micrometers cubed per milliliter or liter) (Blomqvist and Herlitz, 1998; Olrik and others, 1998). Bottle type, volume, and preservative used depend on the laboratory doing the analysis. Because there can be great variability among analysts, it is important to confirm counting and processing methodologies before the analysis, including subsample preparation, counting threshold, taxonomic references, and the experience of the analyst. This is particularly important when using multiple laboratories for analysis. Cyanobacteria are considered to be part of the phytoplankton community, and there is no difference between samples collected for cyanobacterial analysis and phytoplankton analysis. More detail on how to collect and process phytoplankton samples can be found in Hambrook Berkman and Canova (2007).

\section{Sample Shipping}

Samples need to be kept chilled (on ice or refrigerated) and in the dark until shipped. Ideally, samples are shipped on the same day they are collected following the instructions 
Filter with concentrated cyanobacteria

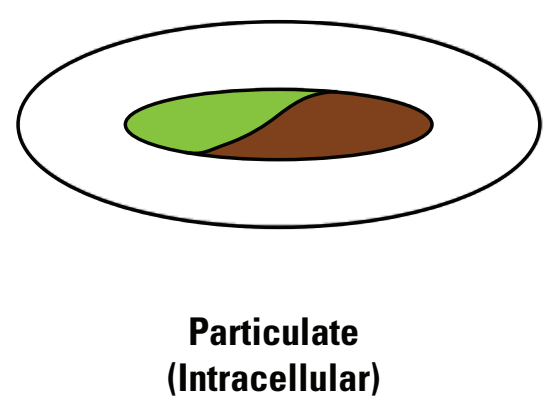

Filtered water sample
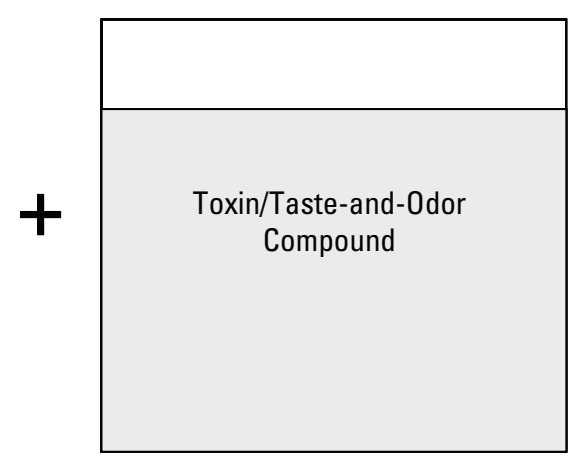

Dissolved

(Extracellular)
Whole water sample

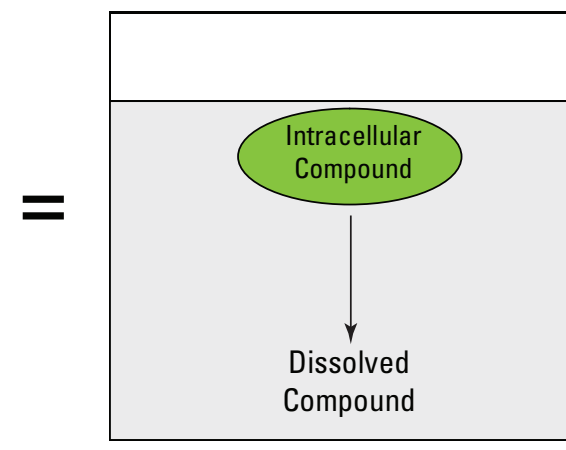

Total (Intracellular + Extracellular)

Figure 9. Partitioning of cyanobacterial toxins and taste-and-odor compounds among the total, particulate (intracellular), and dissolved (extracellular) phases in different types of samples.

provided by the analyzing laboratory. Typically, samples are placed in a cooler, packed with ice (double bagged), and shipped using priority overnight mail so samples arrive at the analyzing laboratory the next morning. Be aware of sample holding times when shipping to areas of the country where there is extreme weather. It is better to hold samples under controlled conditions than to have samples exposed to extreme temperatures for 24 to 48 hours if shipments get delayed.

\section{Commonly Collected Ancillary Data}

The data and additional variables collected during cyanobacterial toxin and taste-and-odor studies will depend entirely on the objectives of the study. Commonly measured variables are listed in table 8 . Generally, all sub-samples for laboratory analyses, including toxin and taste-and-odor analyses, are collected from the same grab or composite sample. The volume of the grab or composite sample needs to be sufficient for all planned analyses.

\section{Safety Considerations}

Cyanobacterial toxins are known to cause human illness, and skin contact may result in irritation and rash. Gloves always need to be worn when collecting samples for cyanobacterial toxin and taste-and-odor analysis. Skin and eye contact with dense surface accumulations need to be avoided. If dense surface accumulations are going to be sampled, gloves that extend to the shoulder may be required. If contact with dense surface accumulations occurs, the affected area needs to be rinsed immediately with clean water. Because inhalation of aerosols may be a problem for those with respiratory illness, precautions also need to be taken if sampling personnel have a recent history of asthma or respiratory disease. Other general safety considerations are discussed in NFM chapter 9 (Lane and Fay, 1997).

\section{U.S. Geological Survey National Water Information System Parameter Codes}

Many of the cyanobacterial toxin and taste-and-odor compounds already have parameter codes available for entry into the USGS National Water Information System (NWIS) and updates are made as new compounds and analyses become available. Check the NWIS parameter code dictionary to see what codes are available for toxin and taste-and-odor compounds. The parameter code dictionary is available online at: http://waterdata.usgs.gov/nwis/help?codes_help \#Table8.

\section{Summary}

The study of cyanobacterial toxins and taste-and-odor compounds is an active area of developing research. Consistent guidelines for the development of scientific studies of cyanobacteria and associated toxins and taste-and-odor compounds will allow for nationally comparable data sets and among study comparisons. Study objectives and design dictate when, where, and how samples are collected for analysis of cyanobacteria and associated toxins and taste-and-odor compounds and require careful consideration with respect to the unique characteristics of the cyanobacteria. This report 
Table 8. Commonly collected ancillary data for studies of cyanobacterial toxins and taste-and-odor compounds and references for additional information.

[Table modified after Table 7.4-4 (Hambrook Berkman and Canova, 2007) in the U.S. Geological Survey National Field Manual (NFM); GPS, global positioning system]

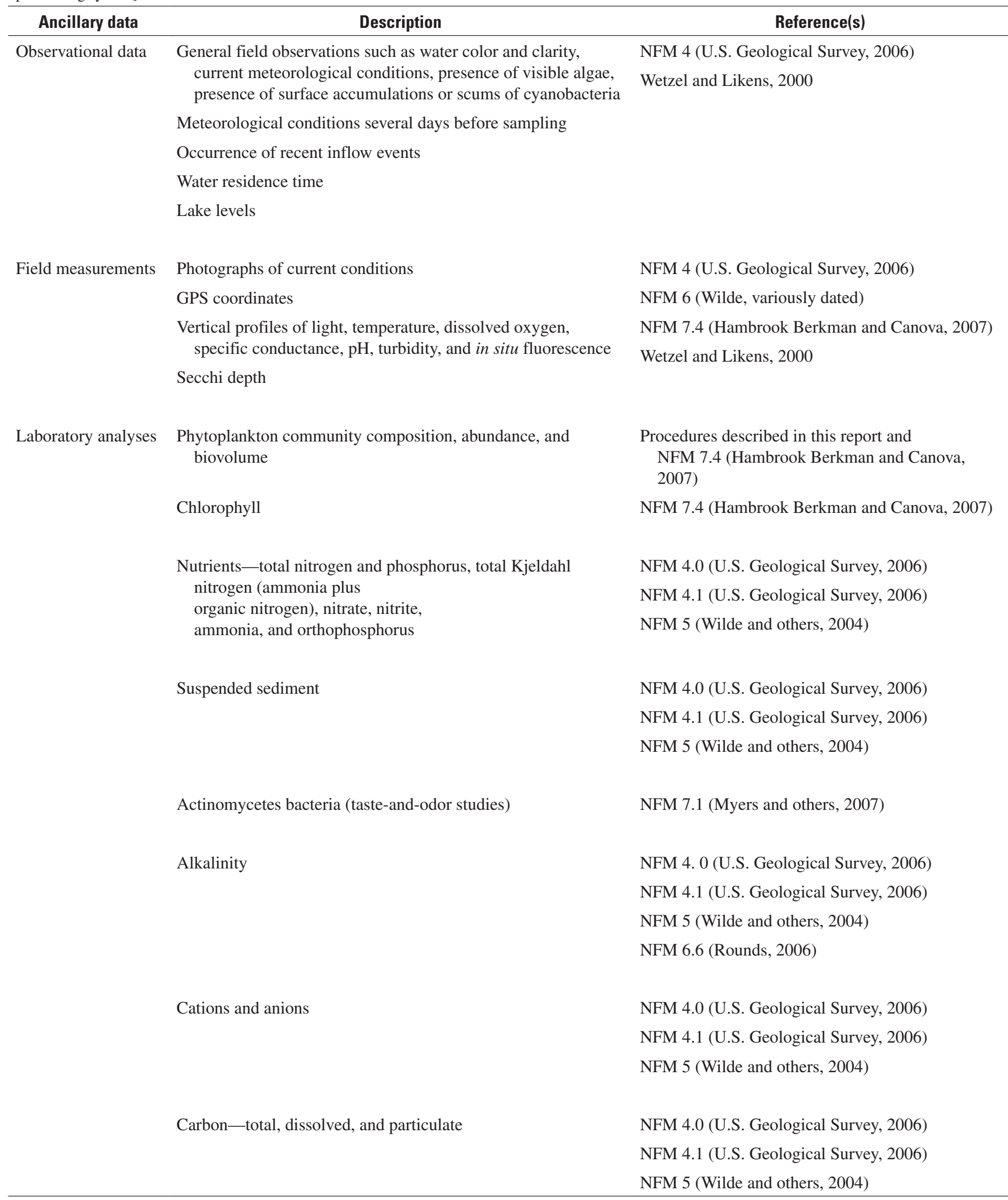


provides general background information on, as well as guidance for, the design of studies assessing cyanobacterial toxin and taste-and-odor compounds in lakes and reservoirs and sample collection approaches for cyanobacterial toxins and taste-and-odor compounds.

\section{Acknowledgements}

The authors thank Laura Simonson, USGS, and Ann St. Amand, of PhycoTech Inc., for their technical reviews, which provided valuable input and resulted in improved report content. We also thank Julie Hambrook Berkman for review and discussion of the initial report outline, Franceska Wilde for her ideas and technical comments throughout the development of this report, and Eric O'Brien for discussions on beach monitoring programs. Our appreciation also goes to Tim Miller, Chief of the USGS Office of Water Quality, for his support in this endeavor.

\section{Selected References}

American Water Works Association, 2004, Problem organisms in water: Identification and treatment ( $3 \mathrm{~d}$ ed.): Denver, CO, American Water Works Association, 165 p.

Averett, R.C., and Schroder, L.J., 1994, A guide to the design of surface-water-quality studies: U.S. Geological Survey Open-File Report 93-105, 39 p.

Barco, M., Lawton, L.A., Rivera, J., Caixach, J., 2005, Optimization of intracellular microcystin extraction for their subsequent analysis by high-performance liquid chromatography: Journal of Chromatography, v. 1074, p. 23-30.

Bláha, L., and Maršálek, B., 1999, Microcystin production and toxicity of picocyanobacteria as a risk factor for drinking water treatment plants: Algological Studies, v. 92, p. 95-108.

Blevins, W.T., Schrader, K.K., and Saadoun, I.M., 1995, Comparative physiology of geosmin production by Streptomyces halstedii and Anabaena sp.: Water Science Technology, v. 31 , no. 11 , p. $127-133$.

Blomqvist, P., and Herlitz, E., 1998, Methods for quantitative assessment of phytoplankton in freshwaters, part 2: Naturvårdsverket, Stockholm, Report 4861, various pagination.

Britton, L.J., and Greeson, P.E., eds., 1987, Methods for collection and analysis of aquatic biological and microbiological samples: United States Geological Survey Techniques of Water-Resources Investigations, book 5, chap. A4, 363 p.
Carmichael, W.W., 1997, The cyanotoxins: Advances in Botanical Research, v. 27, p. 211-256.

Carmichael, W.W., Azevedo, S.M.F.O., An, J.S., Molica, R.J.R., Jochimsen, E.M., Lau, S., Rinehart, K.L., Shaw, G., and Eaglesham, G.K., 2001, Human fatalities from cyanobacteria: chemical and biological evidence for cyanotoxins: Environmental Health Perspectives, v. 109, no. 7 , p. 663-668.

Carmichael, W.W., and Gorham, P.R., 1981, The mosaic nature of toxic blooms of cyanobacteria, in Carmichael, W.W., ed., The water environment-Algal toxins and health: New York, Plenum Press, p. 161-173, 491 p.

Chiswell, R.K., Shaw, G.R., Eaglesham, G.K., Smith, M.J., Norris, R.L., Seawright, A.A., and Moore, M.R., 1999, Stability of cylindrospermopsin, the toxin from the Cyanobacterium, Cylindrospermopsis raciborskii: Effect of $\mathrm{pH}$, temperature, and sunlight on decomposition: Environmental Toxicology, v. 14, p. 155-161.

Chorus, I., 1993, Algal metabolites and water quality: Toxins, allergens, and taste-and-odor-substances, in de Bernardi, R., Pagnotta, R., and Pagnotta, A., eds., Strategies for lake ecosystems beyond 2000, Memorie dell'Instituto Italiano di Idrobiologia, p. 257-280.

Chorus, I., ed., 2001, Cyanotoxins: Occurrence, causes, consequences: Berlin, Springer, 357 p.

Chorus, I., and Bartram, J., eds., 1999, Toxic cyanobacteria in water: London, WHO, E \& FN Spon, 416 p.

Christensen, V.G., Graham, J.L., Milligan, C.R., Pope, L.M., and Ziegler, A.C., 2006, Water quality and relation to taste-and-odor compounds in the North Fork Ninnescah River and Cheney Reservoir, south-central Kansas, 19972003: U.S. Geological Survey Scientific Investigations Report 2006-5095, 43 p.

Christofferson, K., 1996, Ecological implications of cyanobacterial toxins in aquatic food webs: Phycologia, v. 35, no. 6 Supplement, p. 42-50.

Clesceri, L.S., Greenburg, A.E., and Eaton, A.D., eds., 1998, Standard methods for the examination of water and wastewater (20th ed.): Washington D. C., American Public Health Association, 1,325 p.

Cottingham, P., Bennison, G., Dunn, R., Lidston, J., and Robinson, D., 1995, Algal bloom and nutrient status of Victorian inland waters: Government of Victoria, $154 \mathrm{p}$.

Cousins, I.T., Bealing, D.J., James, H.A., and Sutton, A., 1996, Biodegradation of microcystin-LR by indigenous mixed bacterial populations: Water Research, v. 30, no. 2, p. 481-485. 
Cox, P.A., Banack, S.A., Murch, S.J., Rasmussen, U., Tien, G., Bidigare, R.R., Metcalf, J.S., Morrison, L.F., Codd, G.A., and Bergman, B., 2005, Diverse taxa of cyanobacteria produce B-N-methylamino-L-alanine, a neurotoxic amino acid: Proceedings of the National Academy of Sciences of the United States of America, v. 102, no. 14, p. 5,074-5,078.

Dahlmann, J., Budakowski, W.R., Luckas, B., 2003, Liquid chromatography-electrospray ionization-mass spectrometry based method for the simultaneous determination of algal and cyanobacterial toxins in phytoplankton from marine waters and lakes followed by tentative structural elucidation of microcystins: Journal of Chromatography, v. 994, p. $45-57$.

Dell'Aversano, C., Eaglesham, G.K., Quilliam, M.A., 2004, Analysis of cyanobacterial toxins by hydrophilic interaction liquid chromatography-mass spectrometry: Journal of Chromatography, v. 1028, p. 155-164.

Devic, E., Li, D., Dauta, A., Henriksen, P., Codd, G.A., Marty, J.-L., Fournier, D., 2002, Detection of anatoxin-a(s) in environmental samples of cyanobacteria by using a biosensor with engineered acetylcholinesterases: Applied and Environmental Microbiology, v. 68, no. 8, p. 4,102-4,106.

Dodds, W.K., 2002, Freshwater ecology: Concepts and environmental applications: San Diego, California, Academic Press, 569 p.

Domingos, P., Rubim, T.K., Molica, R., Azevedo, S.M.F.O., and Carmichael, W.W., 1999, First report of microcystin production by picoplanktonic cyanobacteria isolated from a northeastern Brazilian drinking water supply: Environmental Toxicology, v. 14, p. 31-35.

Edwards, C., Beattie, K.A., Scrimbeour, C.M., Codd, G.A., 1992, Identification of anatoxin-a in benthic cyanobacteria (blue-green algae) and in associated dog poisonings at Loch Insh, Scotland: Toxicon, v. 30, no. 10, p. 1,165-1,175.

Falconer, I.R., 1993, Mechanism of toxicity of cyclic peptide toxins from blue-green algae, in Falconer, I.R., ed., Algal toxins in seafood and drinking water: London, Academic Press, p. 177-186, 224 p.

Falconer, I.R., 1999, An overview of problems caused by toxic blue-green algae (cyanobacteria) in drinking and recreational water: Environmental Toxicology, v. 14, p. 5-12.

Falconer, I.R., 2005, Cyanobacterial toxins of drinking water supplies: Cylindrospermopsins and microcystins: Boca Raton, Florida, CRC Press, 279 p.

Falconer, I.R., and Humpage, A.R., 2006, Cyanobacterial (blue-green algal) toxins in water supplies: Cylindrospermopsins: Environmental Toxicology, v. 21, p. 299-304.
Fastner, J., Codd, G.A., Metcalf, J.S., Woitke, P., Wiedner, C., Utkilen, H., 2002, International intercomparison exercise for the determination of purified microcystin-LR and microcystins in cyanobacterial field material: Analytical and Bioanalytical Chemistry, v. 374, p. 437-444.

Friedman, L.C., and Erdmann, D.E., 1982, Quality assurance practices for the chemical and biological analyses of water and fluvial sediments: U.S. Geological Survey Techniques of Water-Resources Investigations, book 5, chap. A6, 181 p.

Gjølme, N., and Utkilen, H., 1994, A simple and rapid method for extraction of toxic peptides from cyanobacteria, in Codd, G.A., Jefferies, T.M., Keevil, C.W., and Potter, E., eds., Detection methods for cyanobacterial toxins: The Royal Society of Chemistry, 202 p.

Graham, J.L., 2006, Harmful algal blooms: U.S. Geological Survey Fact Sheet 2006-3147, 2 p.

Graham, J.L., and Jones, J.R., 2007, Microcystin distribution in physical size class separations of natural plankton communities: Lake and Reservoir Management, v. 23, no. 2, p. 161-168.

Graham, J.L., Jones, J.R., Jones, S.B., and Clevenger, T.E., 2006, Spatial and temporal dynamics of microcystin in a Missouri reservoir: Lake and Reservoir Management, v. 22, no. 1, p. 59-68.

Hambrook Berkman, J.A., and Canova, M.G., August 2007, Algal biomass indicators (ver. 1.0): U.S. Geological Survey Techniques of Water-Resources Investigations, book 9, chap. A7, section 7.4, accessed December 17, 2007 at http://pubs.water.usgs.gov/twri9A才

Hawkins, P.R., Novic, S., Cox, P., Neilan, B.A., Burns, B.P., Shaw, G., Wickramasinghe, W., Peerapornpisal, Y., Ruangyuttikarn, W., Itayama, T., Saitou, T., Misuochi, M., Inamori, Y., 2005, A review of analytical methods for assessing the public health risk from microcystin in the aquatic environment: Journal of Water Supply: Research and Technology, v. 54.8, p. 509-518.

Heresztyn, T., and Nicholson, B.C., 1997, Nodularin concentrations in Lakes Alexandrina and Albert, South Australia, during a bloom of the cyanobacterium (blue-green alga) Nodularia spumigena and degradation of the toxin: Environmental Toxicology and Water Quality, v. 12, no. 4, p. 273-282.

Hisbergues, M., Christiansen, G., Rouhiainen, L., Sivonen, K., and Börner, T., 2003, PCR-based identification of microcystin-producing genotypes of different cyanobacterial genera: Archives of Microbiology, v. 180, p. 402-410.

Holst, T., Jørgensen, N.O.G., Jørgensen, C., and Johansen, A., 2003, Degradation of microcystin in sediments at oxic and anoxic, denitrifying conditions: Water Research, v. 37, no. 19 , p. 4,748-4,760. 
Horne, A.J., and Goldman, C.R., 1994, Limnology (2d ed.): New York, McGraw-Hill, 576 p.

Huisman, J., Matthijs, H.C.P., and Visser, P.M., eds., 2005 , Harmful cyanobacteria: Dprdrecht, The Netherlands, Springer, $241 \mathrm{p}$.

Humphries, S.E., and Lyne, V.D., 1998, Cyanophyte blooms: The role of cell buoyancy: Limnology and Oceanography, v. 33, no. 1, p. 79-91.

Jacoby, J.M., and Kann, J., 2007, The occurrence and response to toxic cyanobacteria in the Pacific Northwest, North America: Lake and Reservoir Management, v. 23, no. 2, p. 123-143.

Johnston, B.R., and Jacoby, J.M., 2003, Cyanobacterial toxicity and migration in a mesotrophic lake in Western Washington, USA: Hydrobiologia, v. 495, p. 79-91.

Jones, G.J., and Korth, W., 1995, In situ production of volatile odour compounds by river and reservoir phytoplankton populations in Australia: Water Science \& Technology, v. 31 , no. 11 , p. $145-151$.

Jones, G.J., and Orr, P.T., 1994, Release and degradation of microcystin following algicide treatment of a Microcystis aeruginosa bloom in a recreational lake, as determined by HPLC and protein phosphatase inhibition assay: Water Research, v. 28, no. 4, p. 871-876.

Jungmann, D., Ludwichowski, K.-U., Faltin, V., and Benndorf, J., 1996, A field study to investigate environmental factors that could effect microcystin synthesis of a Microcystis population in the Bautzen reservoir: International Review of Hydrobiology, v. 81, no. 4, p. 493-501.

Kato, H., Imanishi, S.Y., Tsuji, K., and Harada, K.-I., 2007, Microbial degradation of cyanobacterial cyclic peptides: Water Research, v. 41, p. 1,754-1,762.

Kiviranta, J., Sivonen, K., Lahti, K., Luukkainen, R., and Niemela, S.I., 1991, Production and biodegradation of cyanobacterial toxins-A laboratory study: Archiv Fur Hydrobiologie, v. 121, no. 3, p. 281-294.

Kotak, B.G., Lam, A.K.-Y., Prepas, E.E., and Hrudey, S.E., 2000 , Role of physical and chemical variables in regulating microcystin-LR concentration in phytoplankton of eutrophic lakes: Canadian Journal of Fisheries and Aquatic Sciences, v. 57 , no. 8 , p. $1,584-1,593$.

Kurmayer, R., and Kutzenberger, T., 2003, Application of real-time PCR for quantification of microcystin genotypes in a population of the toxic cyanobacterium Microcystis sp.: Applied and Environmental Microbiology, v. 69, no. 11, p. 6,723-6,730.
Lampert, W., and Sommer, U., 1997, Limnoecology: The ecology of lakes and streams: Oxford, Oxford University Press, $382 \mathrm{p}$.

Lanaras, T., Tsitsamis, S., Chlichlia, C., and Cook, C.M., 1989, Toxic cyanobacteria in Greek freshwaters: Journal of Applied Phycology, v. 1, p. 67-73.

Lanckmans, K., Sarre, S., Smolders, I., and Michotte, Y., 2008, Quantitative liquid chromatography/mass spectrometry for the analysis of microdialysates: Talanta, v. 74, p. $458-469$.

Lane, S.L., and Fay, R.G., October 1997, Safety in field activities: U.S. Geological Survey Techniques of WaterResources Investigations, book 9, chap. A9, accessed December 17, 2007 at http://pubs.water.usgs.gov/twri9A9/

Lane, S.L., Flanagan, Sarah, and Wilde, F.D., March 2003, Selection of equipment for water sampling (ver. 2.0): U.S. Geological Survey Techniques of Water-Resources Investigations, book 9, chap. A2, accessed December 17, 2007 at http://pubs.water.usgs.gov/twri9A2

Llewellyn, L.E., Negri, A.P., Doyle, J., Baker, P.D., Beltran, E.C., Neilan, B.A., 2001, Radioreceptor assays for sensitive detection and quantitation of saxitoxin and its analogues from strains of the freshwater cyanobacterium, Anabaena circinalis: Environmental Science and Technology, v. 35, no. 7 , p. $1,445-1,451$.

Long, B.M., Jones, G.J., and Orr, P.T., 2001, Cellular microcystin content in N-limited Microcystis aeruginosa can be predicted from growth rate: Applied and Environmental Microbiology, v. 67, no. 1, p. 278-283.

Mau, D.P., Ziegler, A.C., Porter, S.D., and Pope, L.M., 2004, Surface-water-quality conditions and relation to taste-andodor occurrences in the Lake Olathe watershed, northeast Kansas, 2000-02: U.S. Geological Survey Scientific Investigations Report 2004-5047, 95 p.

Metcalf, J.S., Beattie, K.A., Ressler, J., Gerbersdorf, S., Pflugmacher, S., Codd, G.A., 2002, Cross-reactivity and performance assessment of four microcystin immunoassays with detoxication products of the cyanobacterial toxin, microcystin-LR: Journal of Water Supply Research and Technology, v. 51 , no. 3 , p. 145-151.

Metcalf, J.S., Codd, G.A., 2003, Analysis of cyanobacterial toxins by immunological methods: Chemical Research in Toxicology, v. 16, no. 2, p. 104-111.

Msagati, T.A.M, Siame, B.A., Shushu, D.D., 2006, Evaluation of methods for the isolation, detection and quantification of cyanobacterial hepatotoxins: Aquatic Toxicology, v. 78, p. 382-397. 
Myers, D.N., Stoeckel, D.M., Bushon, R.N., Francy, D.S., and Brady, A.M.G., February 2007, Fecal indicator bacteria (ver. 2.0): U.S. Geological Survey Techniques of WaterResources Investigations, book 9, chap. A7, section 7.1, accessed December 17, 2007 at http://pubs.water.usgs.gov/ twri9A7

Nicholson, B.C., Burch, M.D., 2001, Evaluation of analytical methods for detection and quantification of cyanotoxins in relation to Australian drinking water guidelines: National Health and Medical Research Council of Australia, Water Services Association of Australia, and Cooperative Research Centre for Water Quality and Treatment, $57 \mathrm{p}$.

Nicholson, B., Papageorgiou, J., Humpage, A., Steffensen, D., Monis, P., Linke, T., Fanok, S., Shaw, G., Eaglesham, G., Davis, B., Wickramasinghe, W., Stewart, I., Carmichael, W., Servaites, J., 2007, Determination and significance of emerging algal toxins (cyanotoxins): AWWA Research Foundation and CRC for Water Quality and Treatment, $140 \mathrm{p}$.

Nonneman, D., and Zimba, P.V., 2002, A PCR-based test to assess the potential for microcystin occurrence in channel catfish production ponds: Journal of Phycology, v. 38, p. 230-233.

Olrik, K., Blomqvist, P., Brettum, P., Cronberg, G., and Eloranta, P., 1998, Methods for quantitative assessment of phytoplankton in freshwaters, part I: Naturvårdsverket, Stockholm, Report 4860, 86 p.

Orr, P.T., and Jones, G.J., 1998, Relationship between microcystin production and cell division rates in nitrogen-limited Microcystis aeruginosa cultures: Limnology and Oceanography, v. 43, no. 7, p. 1,604-1,614.

Osswald, J., Rellán, S., Gago, A., Vasconcelos, V., 2007, Toxicology and detection methods for the alkaloid neurotoxin produced by cyanobacteria, anatoxin-a: Environment International, v. 33, p. 1,070-1,089.

Ou, D., Song, L., Gan, N., and Chen, W., 2005, Effects of microcystins on and toxin degradation by Poterioochromonas sp.: Environmental Toxicology, v. 20, p. 373-380.

Oudra, B., Loudiki, M., Vasconcelos, V.M., Sabour, B., Sbiyyaa, B., Oufdou, K., and Mezrioui, N., 2002, Detection and quantification of microcystins from cyanobacteria strains isolated from reservoirs and ponds in Morocco: Environmental Toxicology, v. 17, p. 32-39.

Rashash, D.M.C., Hoehn, R.C., Dietrich, A.M., Grizzard, T.J., and Parker, B.C., 1996, Identification and control of odorous algal metabolites: AWWA Research Foundation and American Waterworks Association, Report 0-89867-855-2, $172 \mathrm{p}$.
Reynolds, C.S., 1984, The ecology of freshwater phytoplankton: Cambridge, Cambridge University Press, 384 p.

Reynolds, C.S., 1987, Cyanobacterial water blooms: Advances in Botanical Research, v. 13, p. 67-143.

Reynolds, C.S., 1998, What factors influence the species composition of phytoplankton in lakes of different trophic status?: Hydrobiologia, v. 369/370, p. 11-26.

Reynolds, C.S., and Walsby, A.E., 1975, Water-blooms: Biological Reviews, v. 50, p. 437-481.

Rounds, S.A., July 2006, Alkalinity and acid neutralizing capacity (version 3.0): U.S. Geological Survey Techniques of Water-Resources Investigations, book 9, chap. A6, section 6.6, accessed December 17, 2007 at http://pubs.water. usgs.gov/twri9A6/

Saadoun, I.M., Schrader, K.K., and Blevins, W.T., 2001, Environmental and nutritional factors affecting geosmin synthesis by Anabaena sp.: Water Research, v. 35, no. 5, p. 1,209-1,218.

Sager, D., Fries, L., Singhurst, L., and Southard, G., 2007, Guidelines for golden alga Prymnesium parvum management options for ponds and small reservoirs (public waters) in Texas: Texas Parks and Wildlife Department, Report PWD RP T3200-1404, 19 p.

Shampine, W.J., Pope, L.M., and Koterba, M.T., 1992, Integrating quality-assurance in project work plans of the U.S. Geological Survey: U.S. Geological Survey Open-File Report 92-162, 12 p.

Sivonen, K., 1996, Cyanobacteria toxins and toxin production: Phycologia, v. 35, no. 6 supplement, p. 12-24.

Smayda, T.J., 1997, Bloom dynamics: Physiology, behavior, trophic effects: Limnology and Oceanography, v. 42, no. 5, p. 1,132-1,136.

Soranno, P.A., 1997, Factors affecting the timing of surface scums and epilimnetic blooms of blue-green algae in a eutrophic lake: Canadian Journal of Fisheries and Aquatic Sciences, v. 54, p. 1,965-1,975.

Spoof, L., Vesterkvist, P., Lindholm, T., Meriluoto, J., 2003, Screening for cyanobacterial hepatotoxins, microcystins and nodularin in environmental water samples by reversedphase liquid chromatography-electrospray ionization mass spectrometry: Journal of Chromatography, v. 1020, p. 105-119.

Stevens, D.K., and Krieger, R.I., 1991, Stability studies on the cyanobacterial nicotinic alkaloid anatoxin-a: Toxicon, v. 29, no. 2, p. 167-169. 
Stewart, I., Webb, P.M., Schluter, P., and Shaw, G.R., 2006, Recreational and occupational field exposure to freshwater cyanobacteria-A review of anecdotal and case reports, epidemiological studies and the challenges for epidemiologic assessment: Environmental Health: A Global Access Science Source, v. 5, no. 6, p. 1-13.

Taylor, W.D., Losee, R.F., Torobin, M., Izaguirre, G., Sass, D., Khiari, D., and Atasi, K., 2005, Early warning and management of surface water taste-and-odor events: AWWA Research Foundation, 373 p.

Tsuji, K., Nalto, S., Kondo, F., Ishikawa, N., Watanabe, M.F., Suzuki, M., and Harada, K.-I., 1994, Stability of microcystins from cyanobacteria: Effect of light on decomposition and isomerization: Environmental Science and Technology, v. 28 , p. $173-177$.

U.S. Environmental Protection Agency, 2005, The drinking water contaminant candidate list: EPA 815-F-05-001, Office of Water $(4607 \mathrm{M}), 6 \mathrm{p}$.

U.S. Geological Survey, September 2006, Collection of water samples (ver. 2.0): U.S. Geological Survey Techniques of Water-Resources Investigations, book 9, chap. A4, accessed December 17, 2007 at http://pubs.water.usgs.gov/twri9A4/

Vaitomaa, J., Rantala, A., Halinen, K., Rouhiainen, L., Tallberg, P., Mokelke, L., and Sivonen, K., 2003, Quantitative real-time PCR for determination of microcystin synthetase E copy numbers for Microcystis and Anabaena in lakes: Applied and Environmental Microbiology, v. 69, no. 12, p. 7289-7297.

van der Ploeg, M., Tucker, C.S., and Boyd, C.E., 1992, Geosmin and 2-methylisoborneol production by cyanobacteria in fish ponds in the Southeastern United States: Water Science \& Technology, v. 25, no. 2, p. 283-290.

Vézie, C., Brient, L., Sivonen, K., Bertru, G., Lefeuvre, J.-C., and Salkinoja-Salonen, M., 1998, Variation of microcystin content of cyanobacterial blooms and isolated strains in Lake Grand-Lieu (France): Microbial Ecology, v. 35, no. 2, p. 126-135.

Vogeser, M. and Parhofer, K.G., 2007, Liquid chromatography tandem-mass spectrometry (LC-MS/MS) - technique and applications in endocrinology: Experimental and Clinical Endocrinology and Diabetes, v. 115, p. 559-570.

Volterra, L., 1993, Algal toxicity in freshwater environments: Memorie dell'Instituto Italiano di Idrobiologia, v. 52, p. 281-299.

Watson, S.B., 2003, Cyanobacterial and eukaryotic algal odour compounds: Signals or by-products? A review of their biological activity: Phycologia, v. 42, no. 4, p. 332-350.
Welker, M., Bickel, H., Fastner, J., 2002, HPLC-PDA detection of cylindrospermopsin-opportunities and limits: Water Research, v. 36, p. 4,659-4,663.

Wetzel, R.G., 2001, Limnology (3d ed.): San Diego, Academic Press, $1,006 \mathrm{p}$.

Wetzel, R.G., and Likens, G.E., 2000, Limnological analyses (3d ed.): New York, Springer-Verlag, 429 p.

Wilde, F.D., ed., chapter sections variously dated, Field measurements: U.S. Geological Survey Techniques of Water-Resources Investigations, book 9, chap. A6, accessed December 17, 2007 at http://pubs.water.usgs.gov/twri9A6/

Wilde, F.D., Radtke, D.B., Gibs, Jacob, and Iwatsubo, R.T., eds., April 2004, Processing of water samples (version 2.1): U.S. Geological Survey Techniques of Water-Resources Investigations, book 9, chap. A5, accessed December 17, 2007 at http://pubs.water.usgs.gov/twri9A5/

Wnorowski, A.U., 1992, Tastes and odours in the aquatic environment: A review: Water South Africa, v. 18, no. 3, p. 203-214.

Wnorowski, A.U., and Scott, W.E., 1992, Incidence of offflavors in South African surface waters: Water Science \& Technology, v. 25, no. 2, p. 225-232.

Wu, J.-T., Ma, P.-I., and Chou, T.-L., 1991, Variation of geosmin content in Anabaena cells and its relation to nitrogen utilization: Archives of Microbiology, v. 157, p. 66-69.

Yen, H., Lin, T., Tseng, I., Tung, S., and Hsu, M., 2007, Correlating 2-MIB and microcystin concentrations with environmental parameters in two reservoirs in south Taiwan: Water Science \& Technology, v. 55, no. 5, p. 33-41.

Yoo, R.S., Carmichael, W.W., Hoehn, R.C., and Hrudey, S.E., 1995, Cyanobacterial (blue-green algal) toxins: A resource guide: Denver, AWWA Foundation and the American Water Works Association, $229 \mathrm{p}$.

Zaitlin, B., and Watson, S.B., 2006, Actinomycetes in relation to taste and odour in drinking water: Myths, tenets, and truths: Water Research, v. 40, p. 1,741-1,753.

Zaitlin, B., Watson, S.B., Ridal, J., Satchwill, T., and Parkinson, D., 2003, Actinomycetes in Lake Ontario: Habitats and geosmin and MIB production: Journal of the American Water Works Association, v. 95, no. 2, p. 113-118.

Zimmerman, L.R., Ziegler, A.C., and Thurman, E.M., 2002, Method of analysis and quality-assurance practices by U.S. Geological Survey Organic Geochemistry Research Group-Determination of geosmin and methylisoborneol in water using solid-phase microextraction and gas chromatography/mass spectrometry: U.S. Geological Survey OpenFile Report 02-337, 12 p. 


\section{Glossary}

\section{A}

Actinomycetes bacteria A group of aerobic, gram-positive bacteria that are largely terrestrial organisms associated with soils. The actinomycetes bacteria play a major role in the mineralization of organic matter in soils. Actinomycetes bacteria are not photosynthetic and are not part of the phytoplankton community in lakes and reservoirs.

Acute Single exposure to a relatively high dose of a toxic substance.

Algae Unicellular or simple multicellular photosynthetic organisms containing chlorophyll- $a$; there are numerous groups of algae, most of which are eukaryotic aquatic organisms.

Allelopathy Inhibition or suppression of growth by one species of algae or plant by chemicals produced by another species.

Aphotic zone Region where there is not enough light to support photosynthesis; extends from below the photic zone to the lake bottom.

\section{B}

Benthic Associated with the bottom of a lake or reservoir. After benthos, a term used to describe the bottom of a lake or reservoir.

Bioactive Indicates a substance has an effect on living tissue.

Biovolume The volume of an organism or group of organisms.

Bloom The term bloom, not specific to cyanobacteria, is inexact and subjective. Common definitions include: a large population or extremely high cell densities of phytoplankton (extremely high densities are typically defined as greater than 20,000 to 100,000 cells per milliliter); where proliferation of phytoplankton is dominated by a single or a few species; and visible accumulation of phytoplankton at the water surface.

Blue-green algae See cyanobacteria.
C

Chronic Repeated exposure to relatively low doses of a toxic substance over an extended period of time.

Cyanobacteria Cyanobacteria are true bacteria with a prokaryotic cell structure; however, cyanobacteria also have chlorophyll- $a$, a photopigment characteristic of eukaryotic algae and higher plants. Structurally the cyanobacteria are bacteria-like but functionally the cyanobacteria are algae-like. Cyanobacteria are typically sampled and analyzed as part of phytoplankton (algal) assemblages rather than bacterial assemblages in aquatic ecosystems. Cyanobacteria often are called bluegreen algae.

Cyanotoxins Any of a number of toxins produced by the cyanobacteria. The cyanotoxins include dermatoxins, hepatotoxins, and neurotoxins and impact a wide range of aquatic and terrestrial organisms, including humans.

D

Dermatoxin A toxin that affects the skin and membrane tissues.

Diel Regular cycle over a 24-hour period.

E

Epilimnion The warm, buoyant upper layer of a stratified lake.

Eutrophic High nutrient content and levels of production.

Eutrophication Nutrient enrichment (particularly nitrogen and phosphorus) in aquatic ecosystems leading to increased productivity.

Extracellular Occurring outside of a cell.

$\mathbf{F}$

G

H

Hepatotoxin A toxin that affects the liver.

Hypereutrophic Very high nutrient content and levels of production.

Hypolimnion The cold, dense bottom layer of a stratified lake; the hypolimnion often becomes anoxic (little or no dissolved oxygen) in productive systems. 
Icthyotoxin A toxin that affects fish or is specific to fish.

Intracellular Occurring within a cell. Intraperitoneal Within the abdominal cavity.

J

K

Kemmerer Bottle A type of thief sampler used for collecting water samples at discrete depths. The sampler is held open at both ends and lowered vertically through the water column. At the desired depth a mechanism triggers the sampler and it closes, capturing the water at depth. The main difference between a Kemmerer Bottle and a Van Dorn Bottle is the mechanism used to open and close the bottle. See fig. 2-5A in chapter 2 (Lane and others, 2003) of the U.S. Geological Survey National Field Manual (U.S. Geological Survey, 2006).

L

M

Mesotrophic Moderate nutrient content and levels of production.

Metalimnetic bloom An algal population that develops at the interface between the epilimnion and metalimnion in a stably stratified lake. Metalimnetic blooms most commonly occur in mesotrophic lakes where light penetrates into the metalimnion.

Metalimnion The middle layer of a stratified lake; the metalimnion is characterized by substantial decreases in temperature with depth.

Mixed depth The depth of turbulent mixing; may include all or only a portion of the water column depending on stratification, solar irradiance, and wind.

N

Neurotoxin A toxin that affects the central nervous system.

0

Oligotrophic Low nutrient content and levels of production.

$\mathbf{P}$

Photic (euphotic) zone Region where there is enough light to support photosynthesis; extends from the surface to the depth were light is approximately one percent of that at the surface.

Phytoplankton Algae, including the cyanobacteria, suspended in the water column.

\section{R}

\section{S}

Secondary metabolite Cellular products that are not directly involved in primary cellular processes that support growth and development.

Senesce (senescence) The process of growing old; aging.

Species A distinct kind of organism; the major division of genus.

Strain A group of organisms of the same species that have distinctive characteristics but are not considered a separate species.

$T$

Taste-and-odor compounds Compounds that produce objectionable tastes and odors in finished drinking water.

Thermocline The region where temperature change is greater than of equal to $1^{\circ} \mathrm{C}$ per meter; the terms thermocline and metalimnion are often used synonymously.

Trophic status Level of productivity in an ecosystem.

Turnover Complete isothermal mixing of a previously stratified lake.

U

V

Van Dorn Bottle A type of thief sampler used for collecting water samples at discrete depths. The sampler is held open at both ends and lowered either vertically or horizontally through the water column. At the desired depth a mechanism triggers the sampler and it closes, capturing the water at depth. The main difference between a Van Dorn Bottle and a Kemmerer Bottle is the mechanism used to open and close the bottle. In addition, the Van Dorn Bottle may be held either vertically or horizontally, while the Kemmerer Bottle only can be used in the vertical position. See fig. 2-5B in chapter 2 (Lane and others, 2003) of the U.S. Geological Survey National Field Manual (U.S. Geological Survey, 2006).

W

$\mathbf{x}$

Y

Z 


\section{Appendixes}




\section{Appendix 1. Example Design and Approach for a Regional Reconnaissance Study}

\section{Objective}

Document the occurrence of cyanobacterial toxins and potential toxin producers in all primary recreational and drinking-water supply lakes and reservoirs within a state.

\section{Design and Approach}

Sample frequency: Samples will be collected monthly during June through September, the period when cyanobacterial populations typically peak.

Site location: In small lakes and reservoirs, samples will be collected at a single, representative open-water site near the deepest part of the lake or reservoir. In large lakes and reservoirs, samples will be collected at representative openwater sites in each of the main basins (lakes) or tributary arms, including a site near the dam (reservoirs). If present, samples from surface accumulations of cyanobacteria also will be collected.

Sample type: Integrated photic zone samples will be collected from open-water sites. Surface grab samples will be collected from surface accumulations.

Sampler used: Samples will be collected every meter throughout the photic zone using a vertical Van Dorn bottle. The samples from each depth will be composited in a churn.
An open-mouth bottle sampler will be used for surface grab samples.

Type of toxin analysis: Toxin samples will be analyzed for total (particulate plus dissolved) toxin concentrations.

Ancillary data collected: At each sample site, photographs and global positioning system (GPS) coordinates will be recorded and Secchi depth and vertical profiles of light (irradiance), water temperature, dissolved oxygen, conductivity, $\mathrm{pH}$, turbidity, and in situ fluorescence will be measured. In addition to cyanobacterial toxins, each sample will be analyzed for phytoplankton community composition, abundance, and biovolume; chlorophyll; total phosphorus and nitrogen; and suspended sediment.

Results: The results from this study can give an indication of how frequently cyanobacterial toxins occur in the state, which toxins are most common, and the range of typical concentrations. Potential cyanobacterial toxin producers also will be identified. General water-quality conditions in the state during peak periods of cyanobacterial abundance will be described. This study will not give a good indication of maximum toxin concentrations; monthly samples may miss periods of peak cyanobacterial toxin abundance. 


\section{Field Form}

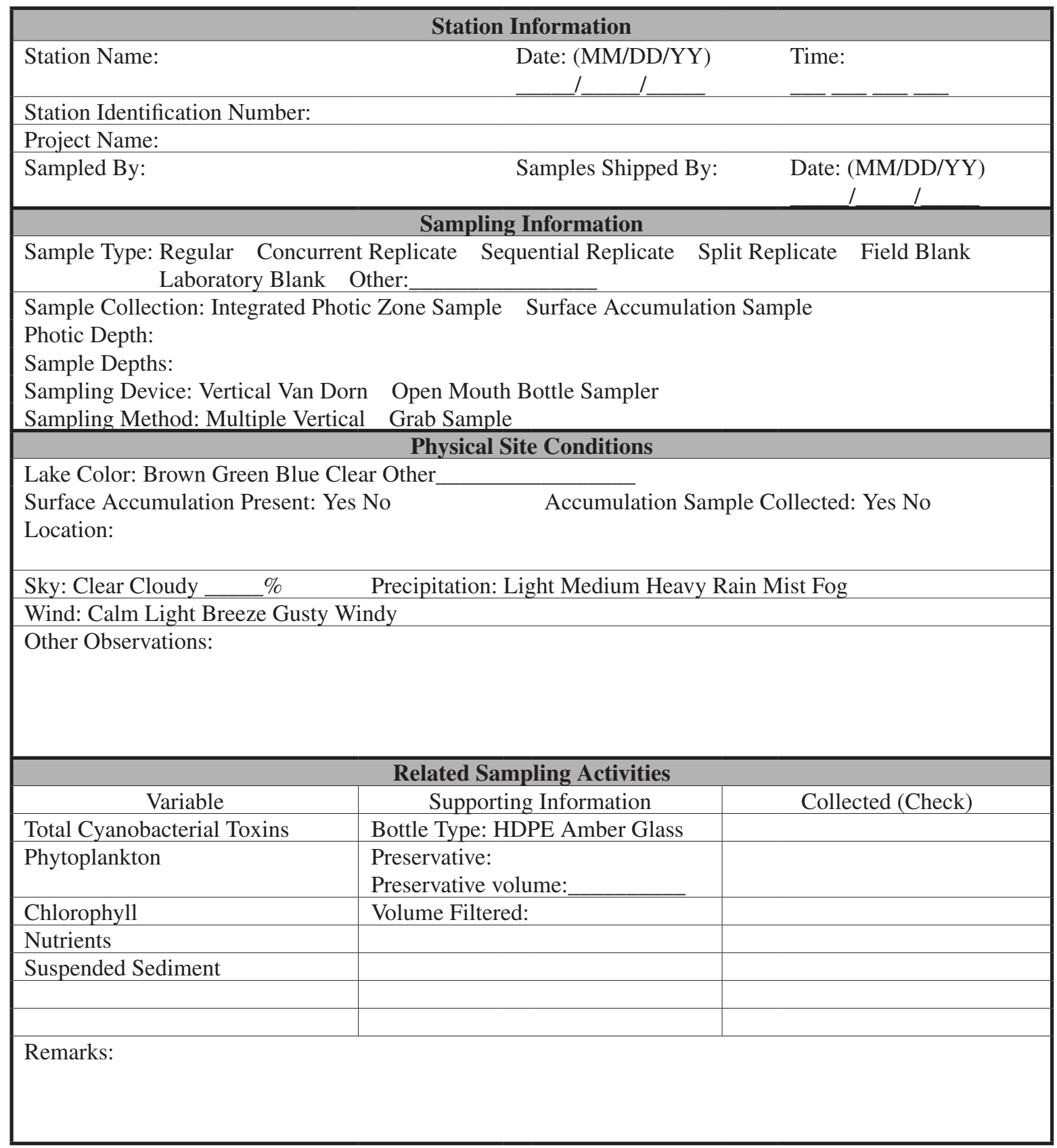


Field Form (continued)

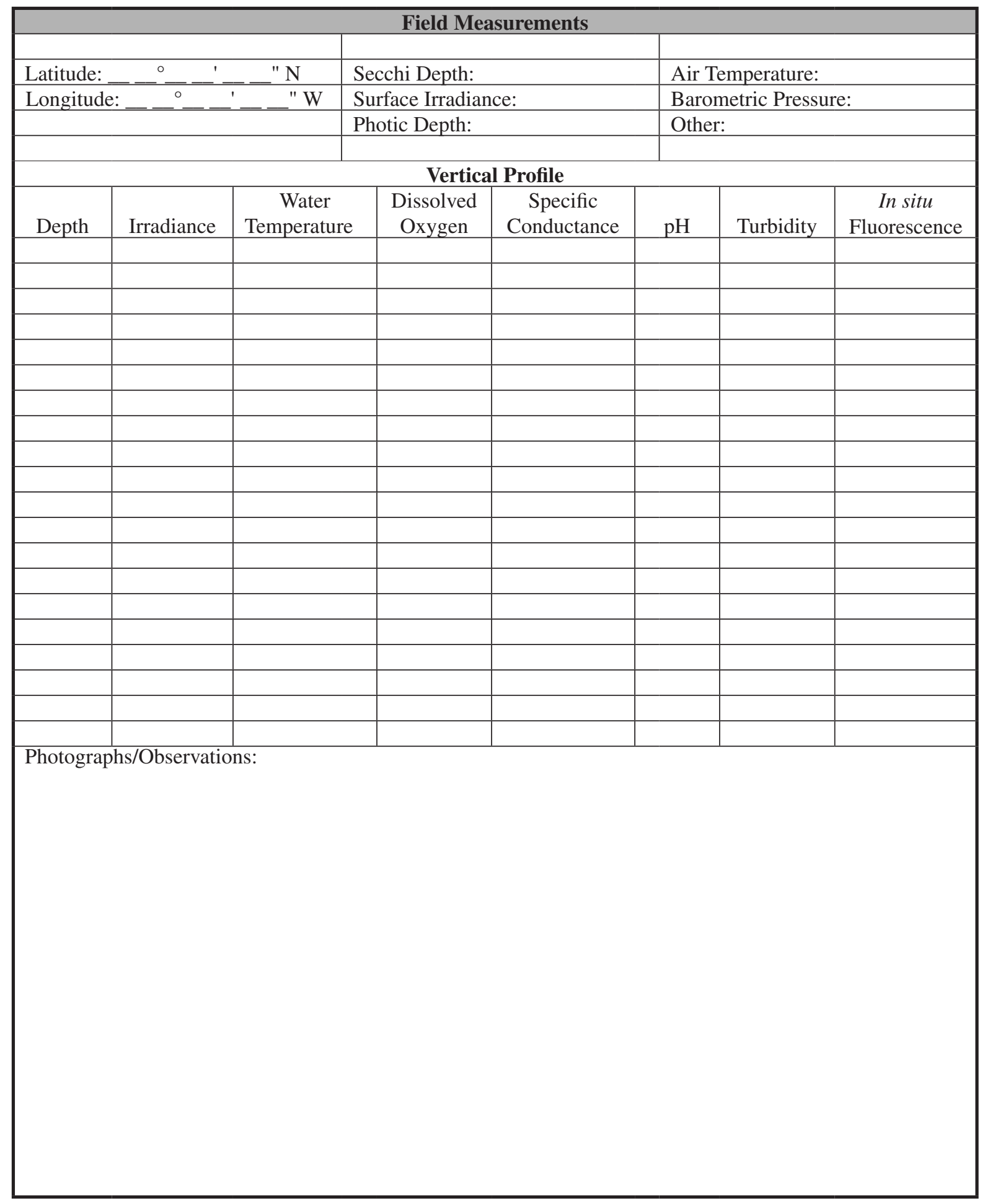




\section{Appendix 2. Example Design and Approach for a Recreational Monitoring Study}

\section{Objective}

Monitor a recreational beach to determine if cyanobacterial toxins pose an acute exposure risk.

\section{Design and Approach}

Sample frequency: Samples will be collected weekly between Memorial Day and Labor Day, the periods of peak recreational use. If cyanobacteria accumulate in the beach area, daily samples will be collected until the accumulation dissipates.

Site location: Samples will be collected from nine locations within the designated recreational area and composited. The nine locations will be determined by evenly dividing the recreational area into three transects that begin at the beach and extend into the water. Samples will be collected from three locations (ankle, knee, and chest deep) along each transect. Sample collection starts at the waters edge in ankle-deep water and continues into the water to approximately chest depth. Ankle-deep water samples will be collected approximately $0.15 \mathrm{~m}$ below the surface. Knee- and chest-deep water samples will be collected approximately $0.30 \mathrm{~m}$ below the surface. If dense cyanobacterial accumulations are present outside of transect locations, an additional sample will be collected from the accumulation.
Sample type: Surface grab samples will be collected. At knee and chest deep locations samples will be collected approximately 15 centimeters below the water surface. Dense cyanobacterial accumulations will be sampled at the water surface.

Sampler used: Grab samples will be collected with an open-mouth bottle at each transect location and composited into a churn.

Type of toxin analysis: Toxin samples will be analyzed for total (particulate plus dissolved) toxin concentrations.

Ancillary data collected: At each sample transect global positioning system (GPS) coordinates will be recorded. In addition, photographs will be taken, and Secchi depth, water temperature, dissolved oxygen, conductivity, $\mathrm{pH}$, turbidity, and in situ fluorescence will be measured at one central location in the recreational area.

Results: The results from this study will give an indication of when cyanobacterial toxin concentrations are elevated enough to cause human health concerns. Data collected may be used to post warnings or close recreational areas. Study results also will give an indication of the range of cyanotoxin concentrations in the recreational area and when peak values typically occur. 


\section{Field Form}

\begin{tabular}{|c|c|c|}
\hline \multicolumn{3}{|c|}{ Station Information } \\
\hline Station Name: & Date: (MM/DD/YY) & Time: \\
\hline \multicolumn{3}{|l|}{ Station Identification Number: } \\
\hline \multicolumn{3}{|l|}{ Project Name: } \\
\hline Sampled By: & Samples Shipped By: & Date: $(\mathrm{MM} / \mathrm{DD} / \mathrm{YY})$ \\
\hline \multicolumn{3}{|c|}{ Sampling Information } \\
\hline \multicolumn{3}{|c|}{$\begin{array}{c}\text { Sample Type: Regular Concurrent Replicate Sequential Replicate Split Replicate Field Blank } \\
\text { Laboratory Blank Other: }\end{array}$} \\
\hline \multicolumn{3}{|c|}{$\begin{array}{l}\text { Sample Collection: Surface Grab Sample Surface Accumulation Sample } \\
\text { Sampling Device: Open Mouth Bottle Sampler } \\
\text { Sampling Method: Grab Sample }\end{array}$} \\
\hline \multicolumn{3}{|c|}{\begin{tabular}{|l} 
Physical Site Conditions \\
\end{tabular}} \\
\hline \multicolumn{3}{|c|}{$\begin{array}{l}\text { Lake Color: Brown Green Blue Clear Other__ } \\
\text { Surface Accumulation Present: Yes No } \\
\text { Location: }\end{array}$} \\
\hline Sky: Clear Cloudy & \multicolumn{2}{|c|}{ Precipitation: Light Medium Heavy Rain Mist Fog } \\
\hline \multicolumn{3}{|c|}{ Wind: Calm Light Breeze Gusty Windy } \\
\hline \multicolumn{3}{|c|}{ Field Measurements } \\
\hline Latitude: $\_{ }^{\circ}-{ }^{\prime}-\ldots$ N & Secchi Depth: & $\mathrm{pH}:$ \\
\hline Longitude: $-{ }^{\circ}-{ }^{\prime} \mathrm{W}$ & Water Temperature: & Turbidity: \\
\hline Air Temperature: & Dissolved Oxygen: & In Situ Fluorescence: \\
\hline Barometric Pressure: & Specific Conductance: & Other: \\
\hline \multicolumn{3}{|l|}{ Photographs/Observations: } \\
\hline \multicolumn{3}{|c|}{ Sample Locations } \\
\hline Transect 1 & Transect 2 & Transect 3 \\
\hline $\begin{array}{l}\text { Ankle Depth: } \\
\text { Latitude: } \_-{ }^{\circ}-1 \\
\text { Longitude: }\end{array}$ & $\begin{array}{l}\text { Ankle Depth: } \\
\text { Latitude: } \_-{ }^{\circ}-{ }^{\prime}-{ }^{\prime} \mathrm{N} \\
\text { Longitude: }\end{array}$ & $\begin{array}{l}\text { Ankle Depth: } \\
\text { Latitude: } \_-\frac{\circ}{\circ}-{ }^{\prime}-{ }^{N} \mathrm{~N} \\
\text { Longitude: }\end{array}$ \\
\hline $\begin{array}{l}\text { Knee Depth: } \\
\text { Latitude: }-{ }^{\circ}-1-{ }_{\circ}{ }^{\prime} \mathrm{N} \\
\text { Longitude: }\end{array}$ & $\begin{array}{l}\text { Knee Depth: } \\
\text { Latitude: }-{ }^{\circ}-1-{ }_{\circ}{ }^{\prime} \mathrm{N} \\
\text { Longitude: }\end{array}$ & $\begin{array}{l}\text { Knee Depth: } \\
\text { Latitude: }-{ }^{\circ}-{ }_{\circ}^{\prime}-{ }^{\prime} \mathrm{N} \\
\text { Longitude: }\end{array}$ \\
\hline $\begin{array}{l}\text { Chest Depth: } \\
\text { Latitude: }-1{ }^{\circ}-1 \\
\text { Longitude: }\end{array}$ & $\begin{array}{l}\text { Chest Depth: } \\
\text { Latitude: }-{ }^{\circ}-1 \\
\text { Longitude: }\end{array}$ & $\begin{array}{l}\text { Chest Depth: } \\
\text { Latitude: }-\circ-1-{ }^{\circ}-{ }^{\prime} \mathrm{N} \\
\text { Longitude: }\end{array}$ \\
\hline Remarks: & Remarks: & Remarks: \\
\hline \multicolumn{3}{|c|}{ Related Sampling Activities } \\
\hline Variable & Supporting Information & Collected (Check) \\
\hline Total Cyanobacterial Toxins & $\begin{array}{l}\text { Preservative: } \\
\text { Preservative volume: }\end{array}$ & \\
\hline Remarks: & & \\
\hline
\end{tabular}




\section{Appendix 3. Example Design and Approach for an Interpretive Study to Develop a Real-Time Model to Estimate Geosmin and 2-Methylisoborneol (MIB) Concentrations}

\section{Objective}

Describe the environmental factors that are associated with taste-and-odor episodes caused by cyanobacteria in a drinking-water supply reservoir and develop a real-time model to estimate the probability of geosmin and MIB concentrations exceeding the human detection threshold of 10 nanograms per liter.

\section{Design and Approach}

Sample frequency: Samples will be collected monthly November through April and bi-weekly May through October, when cyanobacteria typically are abundant in the drinkingwater supply reservoir. The sampling regime may need to be adjusted depending on potential ice cover. During a taste-andodor event, sampling frequency will be increased to weekly or semi-weekly. Sample collection will continue for 5 years.

Site location: The main study site will be located within the vicinity of the drinking water intake. Other locations also may be sampled if surface accumulations of cyanobacteria develop.

Sample type: The type of samples collected will depend on vertical structure and distribution of cyanobacteria. Generally, when the water column is stratified, integrated samples will be collected from the epilimnion, metalimnion, and hypolimnion; when the water column is not stratified, integrated photic zone samples will be collected. Surface samples and discrete depth samples also may be collected depending on cyanobacterial distribution.

Sampler used: A pump will be used to collect depthintegrated samples and discrete depth samples. An openmouth bottle sampler will be used to collect surface samples. All sample types will be composited in a churn for sample processing.
Type of taste-and-odor analysis: Taste-and-odor samples will be analyzed for total and dissolved concentrations.

Ancillary data collected: Real-time water-quality monitors will be installed in the photic zone near the drinking water intake, and will measure lake level, light (irradiance), water temperature, dissolved oxygen, conductivity, $\mathrm{pH}$, turbidity, and in situ fluorescence. An anemometer (wind meter) also will be installed at the site. Other meteorological data will be obtained daily from a local weather station and the timing of inflow events will be recorded.

During each sampling, site photographs and global positioning system (GPS) coordinates will be recorded and Secchi depth and vertical profiles of light (irradiance), water temperature, dissolved oxygen, conductivity, $\mathrm{pH}$, turbidity, and in situ fluorescence will be measured. In addition to taste-andodor compounds, each sample will be analyzed for total and dissolved cyanobacterial toxins, phytoplankton community composition, abundance, and biovolume, chlorophyll, actinomycetes bacteria, nutrients, suspended sediment, major ions, and alkalinity.

Results: The results of this study will describe the seasonal patterns in the occurrence of taste-and-odor compounds and give an indication of when taste-and-odor episodes are most likely to occur. In addition, the relations between environmental variables, cyanobacterial community structure, and the occurrence of taste-and-odor compounds will be described, and may indicate potential management options. Real-time data and discrete water-quality samples will allow the development of a real-time model to estimate the probability that taste-and-odor compound concentrations will exceed the human detection threshold. This model can allow the drinkingwater treatment facility to adjust treatment accordingly and minimize the effects of taste-and-odor occurrences on drinking-water quality. 


\section{Field Form}

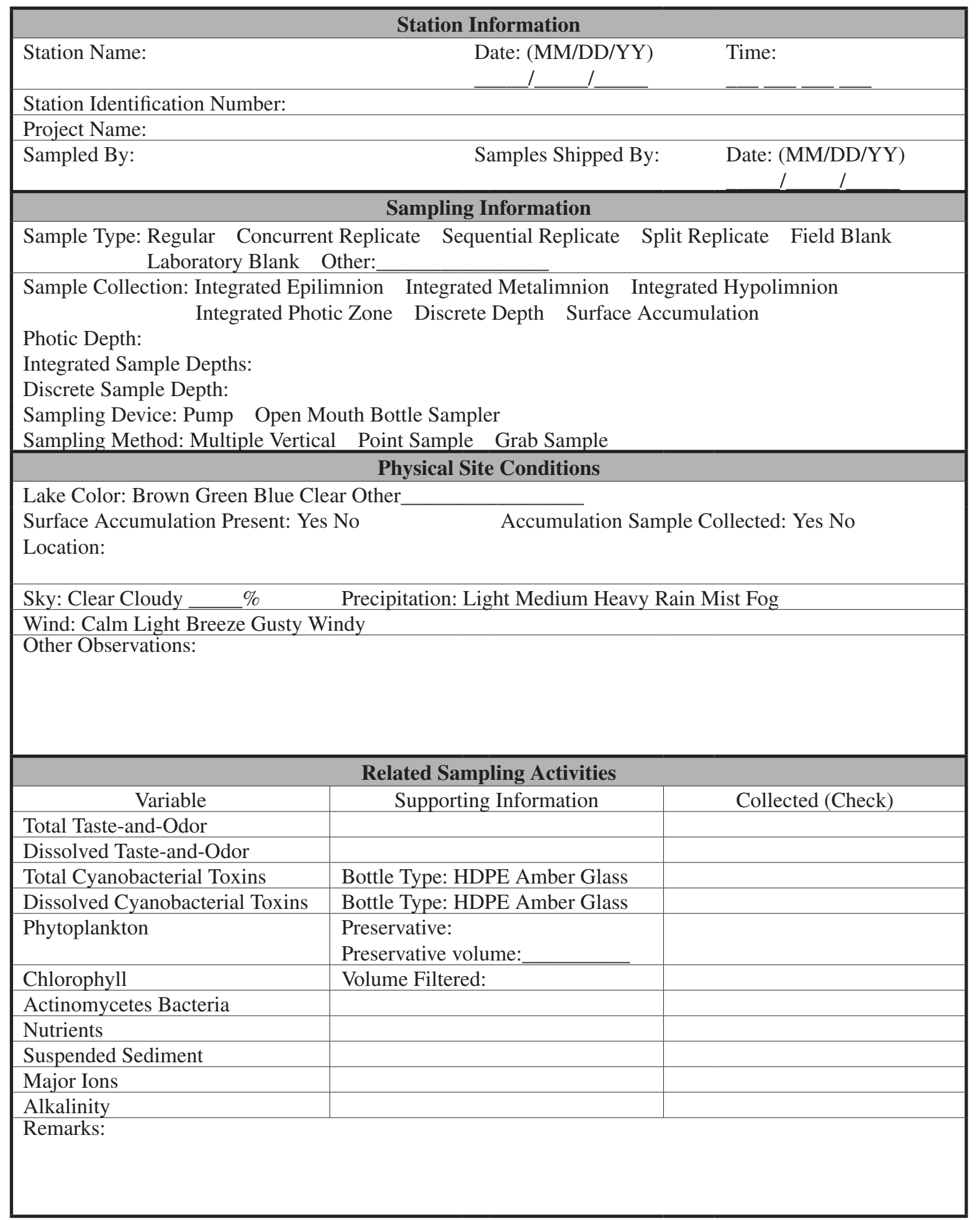


Field Form (continued)

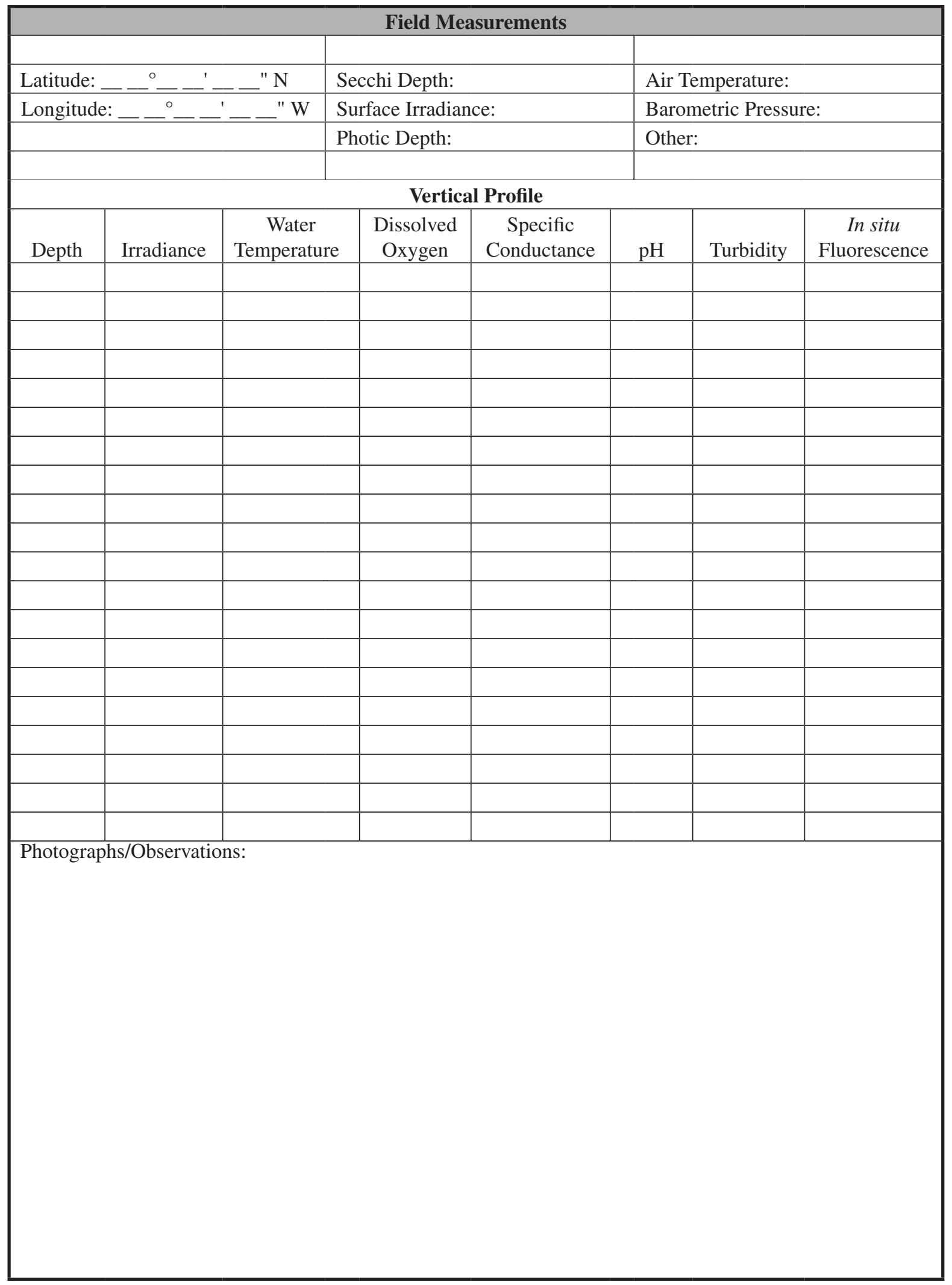


Publishing support provided by:

Rolla Publishing Service Center

For more information concerning this publication, contact:

Director, USGS Kansas Water Science Center

4821 Quail Crest Place

Lawrence, KS 66049

(785) 842-9909

Or visit the Kansas Water Science Center Web site at: http://ks.water.usgs.gov 




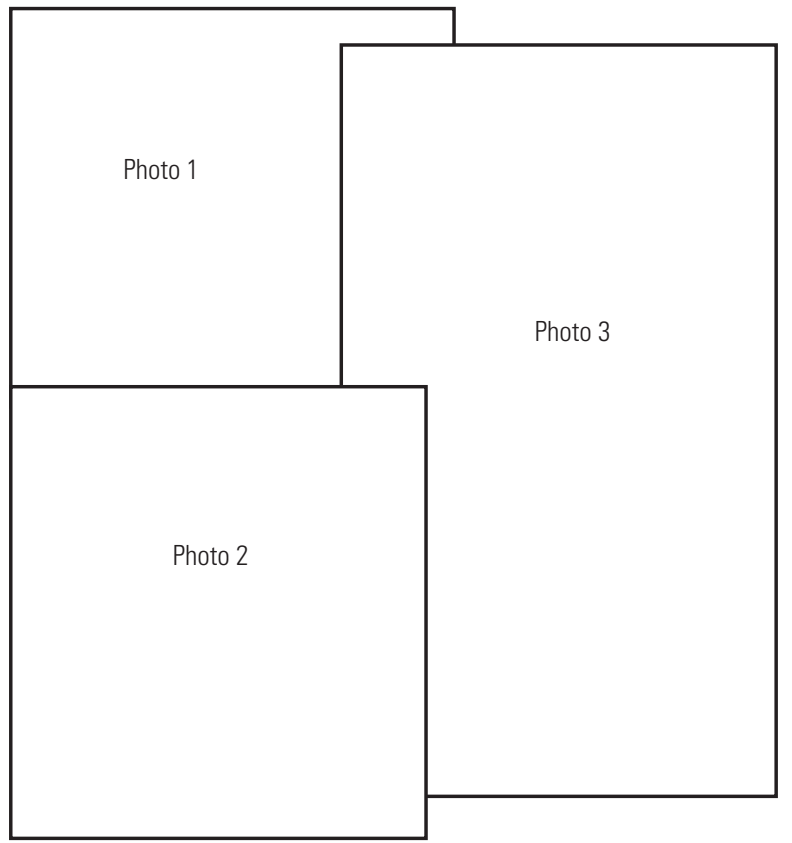

Back cover. Photograph 1: Fish kill associated with a Microcystis bloom, August 8, 2006 (photograph taken by Jennifer L. Graham, U.S. Geological Survey). Photograph 2: Sampling a Planktothrix bloom, August 9, 2006 (photograph taken by Jennifer L. Graham, U.S. Geological Survey). Photograph 3: Wind-blown accumulation of Aphanizomenon and Microcystis in a recreational area, October 11, 2001 (photograph taken by Jennifer L. Graham, U.S. Geological Survey). 

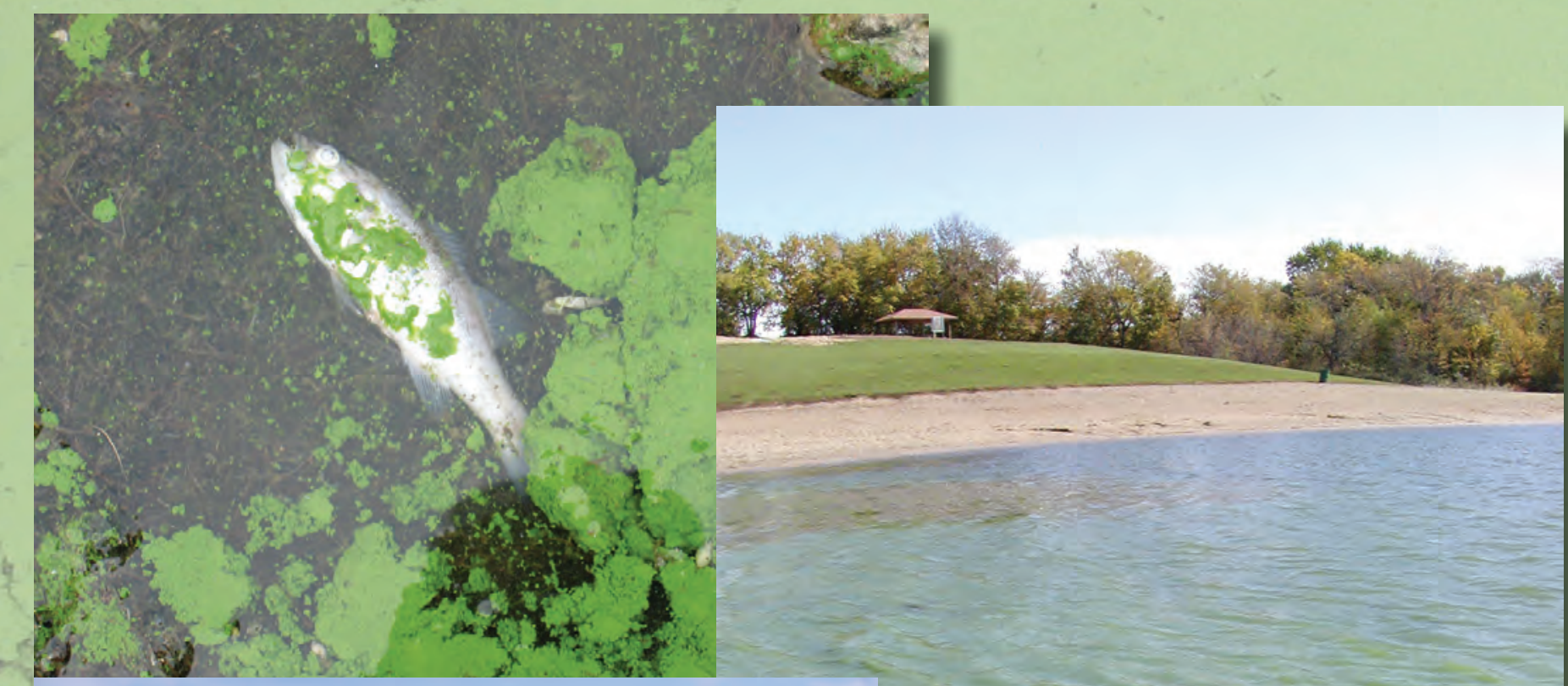

2

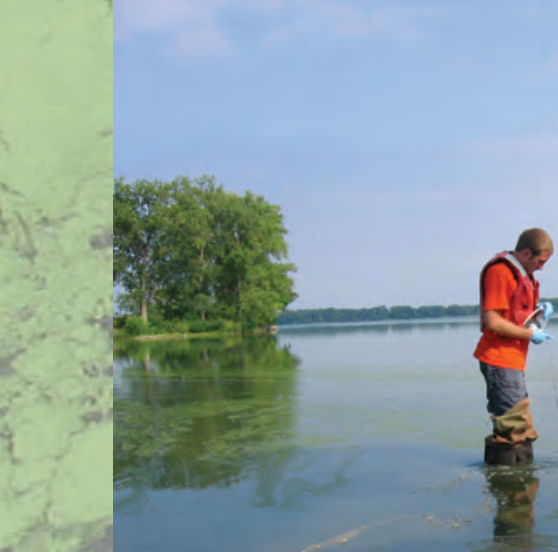

$x \rightarrow \frac{\pi}{2}$
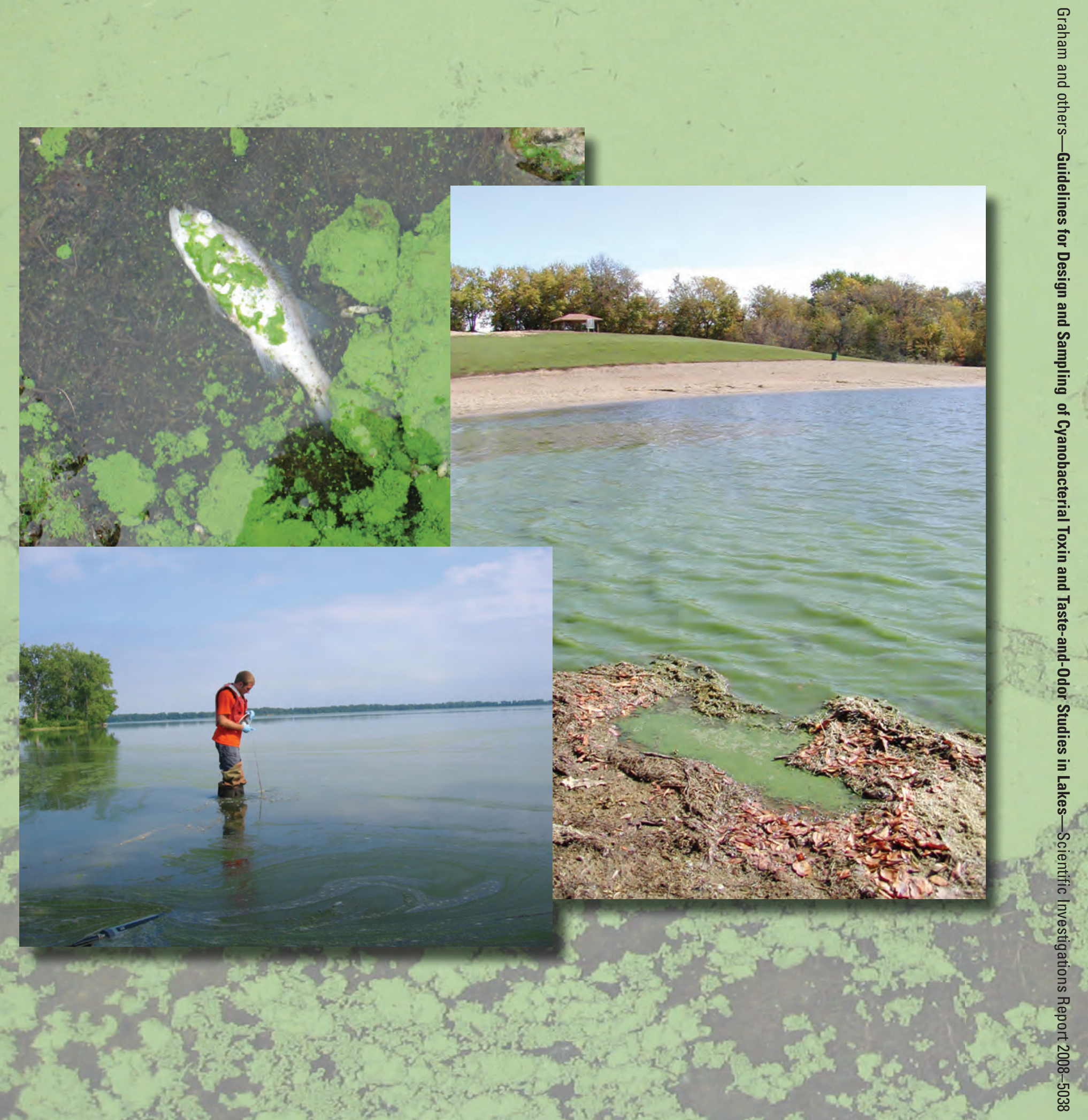

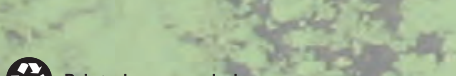

$\theta$

10

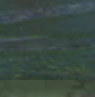

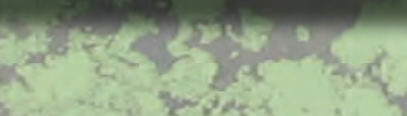
indemin 3
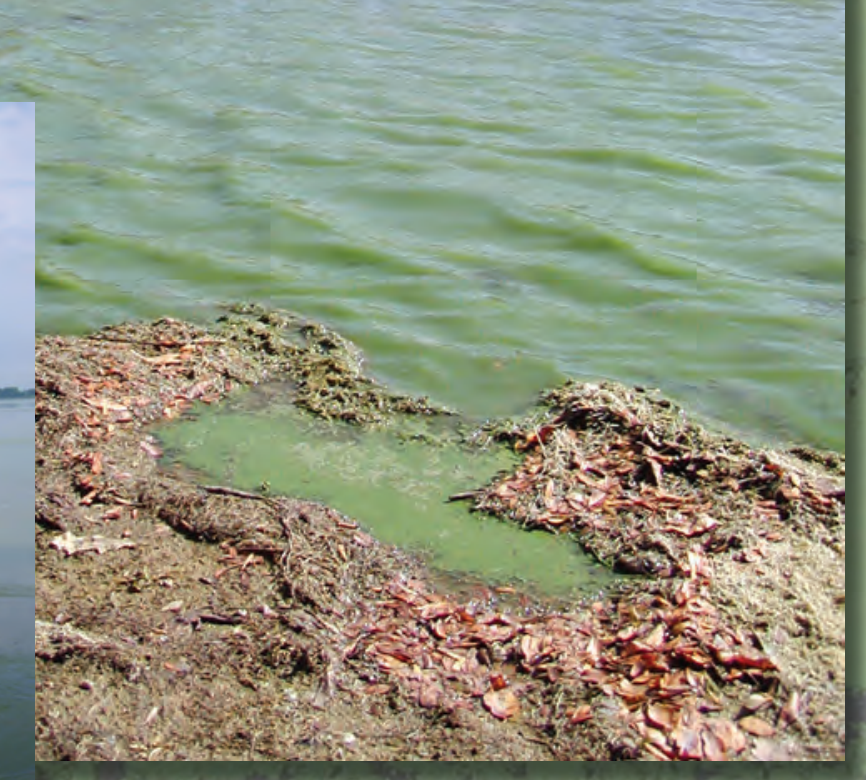